\title{
Report on Notifications Pursuant to $\$ 21$ German Transfusion Act for 2007
}

\author{
Olaf Henseler Margarete Heiden Birgit Haschberger Janina Hesse Rainer Seitz
}

Paul-Ehrlich-Institut, Langen, Germany

\section{Key Words}

Blood donations · Erythrocyte concentrates · Plasma for fractionation . Blood coagulation factors · Supply situation

\section{Summary}

The present report contains the data collected in 2007, pursuant to Section 21 German Transfusion Act, and an analysis of the supply situation over the past 8 years. As in previous years, all blood donation centres located in Germany transmitted data on the collection, manufacture, import and export of blood components for transfusion. According to these data, a total of 6.7 million blood collections were performed in 2007. With 4.7 million, the portion of whole blood donations was at the level of previous years, whereas the number of apheresis donations rose again, to 1.9 million. The portion of autologous blood collections accounts for only $1.1 \%$ and thus continues to decline. Since 2003, the number of red blood cell concentrates prepared has been a constant 4.5 million transfusion units. The decay of red blood cell concentrates on the user side in 2000 accounted for $5 \%$ while in 2007 it was just above 3\%, referred to the total quantity of data reported as transfused and decayed. The manufacture of platelet concentrates rose from 366,000 to 480,000 transfusion units between 2003 and 2007. The production of therapeutic single plasmas, too, markedly increased in 2007 (to 1.2 million transfusion units). In 2007, 2.2 million I of plasma for fractionation were collected in Germany. In addition, 1.0 million I were imported, and 1.8 million I were exported. The quantity available in Germany from a pure arithmetic point of view of 1.4 million I was almost entirely allocated to basic fractionation so that a sufficient plasma supply can be assumed. Due to the fact that manufacturing capacities are still lacking in Germany, recombinant factors need to be imported in their entirety. Since 2003 Germany has by far been the leader in Europe with more than 20 I of fractionation plasma collected per 1,000 inhabitants. Furthermore, regarding the manufacturing figures of red blood cell concentrates, platelet concentrates, and therapeutic single plasma, Germany is in the top third for all these products compared with other European countries. The manufacture of allogeneic stem cell products for haematopoietic reconstitution, obtained by apheresis, has continuously risen to 4,700 . A large portion of this $(1,810$ transplants) could be exported while only a small number (179 preparations) had to be imported. The manufacture of autologous stem cell preparations from cord blood has risen drastically to more than 10,000 in 2007 . The interest in the figures collected in compliance with Section 21, German Transfusion Act remains high both in Germany and at an international level. Meanwhile reliable data are available.

\section{Schlüsselwörter}

Blutspenden · Erythrozytenkonzentrate - Plasma zur Fraktionierung . Gerinnungsfaktoren · Versorgungslage

\section{Zusammenfassung}

Der vorliegende Bericht enthält die nach §21 Transfusionsgesetz (TFG) erhobenen Daten des Jahres 2007 und Auswertungen zur Versorgungssituation im Verlauf der vergangenen 8 Jahre. Wie in den Jahren zuvor haben alle in Deutschland ansässigen Blutspendedienste Angaben zu Gewinnung, Herstellung, Import und Export von Blutkomponenten zur Transfusion übermittelt. Danach wurden im Jahr 2007 insgesamt 6,7 Millionen Entnahmen durchgeführt. Der Anteil der Vollblutspenden lag mit 4,7 Millionen auf dem Niveau der Vorjahre, während die Zahl der Apheresespenden sich erneut auf 1,9 Millionen erhöhte. Der Anteil der Eigenblutentnahmen liegt bei nur noch 1,1\% und ist damit weiter rückläufig. Seit 2003 liegt die Zahl hergestellter Erythrozytenkonzentrate konstant bei 4,5 Millionen Transfusionseinheiten. Der Verfallsanteil von Erythrozytenkonzentraten auf der Anwenderseite ging, bezogen auf die insgesamt als transfundiert und verfallen gemeldete Menge, von über $5 \% \mathrm{im}$ Jahr 2000 auf knapp über 3\% in 2007 zurück. Die Herstellung von Thrombozytenkonzentraten stieg im Zeitraum zwischen 2003 und 2007 von 366000 auf 480000 Transfusionseinheiten an. Auch die Produktion von therapeutischem Einzelplasma wurde $2007 \mathrm{im}$ Vergleich zu den Vorjahren deutlich auf über 1,2 Millionen Transfusionseinheiten gesteigert. In Deutschland wurden 2,2 Millionen I Plasma zur Fraktionierung gewonnen. Zusätzlich wurden 1,0 Millionen I eingeführt und 1,8 Millionen I exportiert. Die rein rechnerisch in Deutschland verfügbare Menge in Höhe von 1,4 Millionen I wurde fast vollständig der Basisfraktionierung zugeführt, so dass von einem ausreichenden Aufkommen an Plasma ausgegangen werden kann. Wegen nach wie vor fehlender Herstellungskapazitäten in Deutschland müssen sämtliche rekombinanten Faktoren eingeführt werden. Mit über $20 \mathrm{I}$ gewonnenen Fraktionierungsplasmas pro 1000 Einwohner ist Deutschland seit 2003 europaweit führend. Auch bei Betrachtung der Herstellungszahlen von Erythrozytenkonzentraten, Thrombozytenkonzentraten und therapeutischem Einzelplasma liegt Deutschland im europäischen Vergleich durchweg im vorderen Drittel. Die Herstellung allogener Stammzellpräparate zur hämatopoetischen Rekonstitution aus Apherese steigt kontinuierlich auf nunmehr 4700. Ein großer Anteil davon (1810 Transplantate) konnte exportiert werden, während nur eine geringe Anzahl von 179 Präparaten importiert werden musste. Auch die Herstellung autologer Stammzellpräparate aus Nabelschnurblut ist im Vergleich zum Jahr 2006 enorm gestiegen, auf über $10000 \mathrm{im}$ Jahr 2007. Das Interesse an den nach §21 TFG erhobenen Zahlen ist in Deutschland und international unverändert hoch. Inzwischen sind auch belastbare Daten verfügbar.

\section{KARGER}

Fax +497614520714

Information@Karger.de www.karger.com

\section{(C) 2010 S. Karger GmbH, Freibur}

Accessible online at:

www.karger.com/tmh
Olaf Henseler

Paul-Ehrlich-Institut

Paul-Ehrlich-Straße 51-59, 63225 Langen, Germany

Tel. +49 6103 77-1862, Fax -1276

henol@pei.de 


\section{Introduction}

Can the population in Germany be supplied with a sufficient amount of medicinal products derived from blood? This is the question to be answered by the annual data collection pursuant to Section 21 German Transfusion Act (Transfusionsgesetz; TFG) on the collection of blood an blood components, the manufacture, imports and exports of blood products and genetically engineered plasma proteins for the treatment of haemostasis disorders, and the consumption and loss of blood products. Comparing the 'as is' with the 'target' side serves to provide an overview of the degree of self-sufficiency.

This also included the question concerning the number of patients with congenital haemostasis disorders requiring treatment, in particular haemophilia patients, and the amount of coagulation factors prescribed for these patients, broken down by patient group and degree of severity of the disease.

This report provides an overview of the data reported in 2007 and the development of selected aspects since 2000 .

\section{Methodology}

Report Forms

Since 2007, report forms have been accessible only online for registered users on www.tfg.pei.de. Access is granted by the Paul-Ehrlich-Institut (PEI).

\section{Collection}

The data to be reported refer to the number of autologous and allogeneic blood donations, stem cell preparations from peripheral and cord blood as well as the amount of plasma as starting material for fractionation.

\section{Manufacture and Consumption}

The data recorded include the manufacture and consumption of blood components, stem cell products, medicinal products derived from human plasma, and coagulation factor products manufactured by genetic engineering. The package units recorded depend on the actual package sizes.

\section{Patients with Congenital Haemostasis Disorders}

The data recorded include the number of haemophilia A and B patients and of patients with von Willebrand's disease. The quantities of coagulation factors consumed for the therapy of these diseases are assigned to age and degree of severity of the disease.

As per reporting year 2008, these data are collected via the German Haemophilia Register ( Deutsches Hämophilieregister; DHR; see $w w w$. pei.de/dhr).

\section{Categorisation of the Reporting Organisations}

In Germany, several organisations are involved in supplying blood products. Accordingly, each organisation is assigned to a group. Strictly speaking, the division between state, local authority-based and charitable organisations on the one hand and private ones on the other can no longer be maintained in its previous form because of the increasing privatisation of the former organisations. To compare the data with those of the previous years, however, it appeared to be useful to keep to the existing classification:

- Blood donor services of the Red Cross:

All blood donor services of the German and the Bavarian Red Cross
Organisations have comparable organisational structures. As a rule, the institutes of the Red Cross operate independently from hospitals and do organise not only blood donations on a large scale but also the provision of the blood components derived from these donations. They have the company structure of a non-commercial GmbH (limited liability company), i.e. they are not profit-orientated and have invested surpluses in medical research for many years.

- State/local authority/non-commercial blood donation services:

Even if these organisations have been privatised in their entirety or in part, their primary role has been maintained. Apart from local provision with blood and blood products (local authority blood donation services) and supplies for own hospitals (university hospitals, local authority and non-commercial hospitals), their responsibilities include research - above all at universities.

- Private donation centres:

These include blood donation and plasmapheresis centres with the corporate form of a $\mathrm{GmbH}$ or AG (joint stock company) not operating on a charitable basis: Only those organisations are included as private institutions, in addition to pharmaceutical companies, which operate on a purely private and profit-orientated basis.

- Plasma-processing companies:

This category contains pharmaceutical companies manufacturing, importing, and exporting coagulation factors or other blood plasma products as well as recombinant coagulation factor products, or selling these products in Germany.

- The separate categorisation of the German Army (Bundeswehr) remains unchanged.

Consuming organisations are classified in the following categories as in the past:

- Hospital

- Panel doctor/dialysis centre/out-patient clinic:

This includes all panel doctors, doctors at dialysis centres and at outpatient clinics that perform out-patient surgery.

- Other medical institutions:

This includes rheumatology centres, rehabilitation centres, geriatric institutions, psychiatric institutions, and blood donation centres which perform transfusions.

- Bundeswehr.

\section{Results and Discussion}

\section{Response}

Compared with the reporting year 2006, the number of those institutions which collect, manufacture import or export blood and blood products and are required to report these data decreased by 85 to 483 . These institutions were predominantly health care institutes collecting autologous blood. On the other hand, the number of consuming institutions increased by 11 to 2,907 .

As in previous years, the response for reports on the collection and manufacture of allogeneic blood components is complete. Missing data concern data on the manufacture and imports of some plasma manufacturing companies with offices outside Germany and reports from hospitals in which autologous blood is collected (table 1).

Compared with 2006, the response for institutions using blood and blood products increased slightly to $73 \%$ (table 2). Further exploration and direct enquiries at the registered institutions are planned for the years to come in order to update 
Table 1. Response from the manufacturers (collection, production, imports, and expo

\begin{tabular}{llrr}
\hline Type of organisation & $\begin{array}{l}\text { Number of } \\
\text { manufacturers }\end{array}$ & \multicolumn{2}{c}{ Notifications } \\
\cline { 3 - 4 } & & $\mathrm{n}$ & $\%$ \\
\hline $\begin{array}{l}\text { State-run or municipal hospitals / } \\
\quad \text { non-profit limited liability }\end{array}$ & 55 & 55 & 100 \\
$\quad$ company & & & \\
Red Cross & 9 & 9 & 100 \\
Plasma processing industry & 17 & 14 & 82 \\
Private donation centre & 20 & 20 & 100 \\
Bundeswehr & 1 & 1 & 100 \\
Facilities collecting autologous blood & 381 & 328 & 86 \\
\cline { 2 - 4 } Total & 483 & 427 & 88 \\
\hline
\end{tabular}

Table 2. Response from the users (consumption)

\begin{tabular}{lrrr}
\hline Type of organisation & $\begin{array}{l}\text { Number of } \\
\text { facilities }\end{array}$ & \multicolumn{2}{l}{ Notifications } \\
\cline { 3 - 4 } & & \multicolumn{1}{l}{$\mathrm{n}$} & \multicolumn{1}{c}{$\%$} \\
\hline Hospital & 1,763 & 1,368 & 78 \\
Panel doctors / dialysis centres / surgery & 1,007 & 692 & 69 \\
Bundeswehr & 1 & 1 & 100 \\
Other medical facilities & 136 & 52 & 38 \\
\cline { 2 - 4 } Total & 2,907 & 2,113 & 73 \\
\hline
\end{tabular}

Table 3. Response from haemophilia treaters

\begin{tabular}{llll}
\hline Type of organisation & $\begin{array}{l}\text { Number of } \\
\text { facilities }\end{array}$ & \multicolumn{2}{l}{ Notifications } \\
\cline { 3 - 4 } & & $\mathrm{n}$ & $\%$ \\
\hline $\begin{array}{l}\text { Panel haemophilia treaters } \\
\begin{array}{l}\text { Haemophilia treatment centre } \\
\quad \text { at hospital }\end{array}\end{array}$ & 69 & 47 & 68 \\
\begin{tabular}{l} 
Total \\
\cline { 2 - 4 }
\end{tabular} & 52 & 51 & 98 \\
\hline
\end{tabular}

the list of institutions required to report and to complete the reports.

Up to 2006 , only around $62 \%$ of the institutions registered treating haemophilia patients submitted their reports. In 2007, the response rate of the haemophilia treaters increased to $81 \%$ (table 3 ). It thus reached the highest rate ever.

\section{Collection of Blood and Blood Products}

Out of the past 8 years, the figure of 2007 for first and multiple allogeneic donations of 6.65 million was outnumbered only in the 'boom year' of 2003 (table 4). From 2000 to 2003, a tremendous rise in plasmapheresis donations could be observed, which can obviously be ascribed to government incentives. This rise even led to a decrease in whole blood donations in 2003. The portion of apheresis donations of the past 8 years fluctuated between $14 \%$ in 2000 and $35 \%$ in 2003 . The number of allogeneic whole blood donations per year has been very stable, with roughly 4.7 million (fig. 1 ).

Compared to 2006, the portion of autologous blood collections within the total amount of donations continued to decrease and is only $1.1 \%$ now, accounting for 76,000 units. This downward trend has continued since the year 2000 (fig. 1). An ever decreasing number of hospitals offer their patients the opportunity of in-house autologous blood collection. In most cases, the collection is carried out by a nearby blood donation service. It was only in 2003 that nearly 500 hospitals reported the collection of autologous blood. This figure halved, i.e. it was only 245 in 2007.

Germany is clearly above the European median, accounting for 58 whole blood donations per 1,000 inhabitants. According to the draft report of the Council of Europe [1] from 2005 , a median of 37 whole blood donations per 1,000 inhabitants were carried out in Europe; Germany thus ranked third in 2005, after Denmark and Greece. Rejman [2] postulated that 40-60 whole blood donations per 1,000 inhabitants yearly would provide optimum availability. It can therefore be concluded that a sufficient amount of blood components for therapeutic use should in principle be available in Germany and that bottlenecks in the availability of donations, e.g. during the holidays, need not necessarily lead to serious supply problems.

\section{Red Blood Cell Concentrates}

Red blood cell concentrates represent the most important medicinal products from whole blood donations - only $0.6 \%$ of the red blood cell concentrates originate from apheresis. Around 4.5 million transfusion units (TU) of red blood cell concentrates have been produced per year since 2004, with minor fluctuations (fig. 2). In 2007, 972 red blood cell concentrates were produced per 1,000 whole blood donations. This means a loss in the processing of donations of around $3.4 \%$, similar to the mean of previous years.

Similarly to previous years, around $75 \%$ of the red blood cell concentrates were produced by the blood donation centres of the German and Bavarian Red Cross. The Red Cross therefore constitutes the most important supplier of this lifesaving medicinal product. The group of government, local authority, and other non-profit institutions accounts for $20 \%$ of the red blood cell supplies. Private institutions, on the other hand, only provide a small portion of the red blood cell supplies with $5 \%$ (fig. 2).

Since the data have been recorded in conformity with Section 21 TFG, there has been a discrepancy between the red blood cells reported as sold, transfused and lost (table 4). The real consumption cannot be deduced directly from the data reported, due to this missing quantity which can either be ascribed to reporting errors or missing response. In order to indicate the 'consumption' of red blood cell concentrates in a plausible way despite this problem, the consumption was cal- 


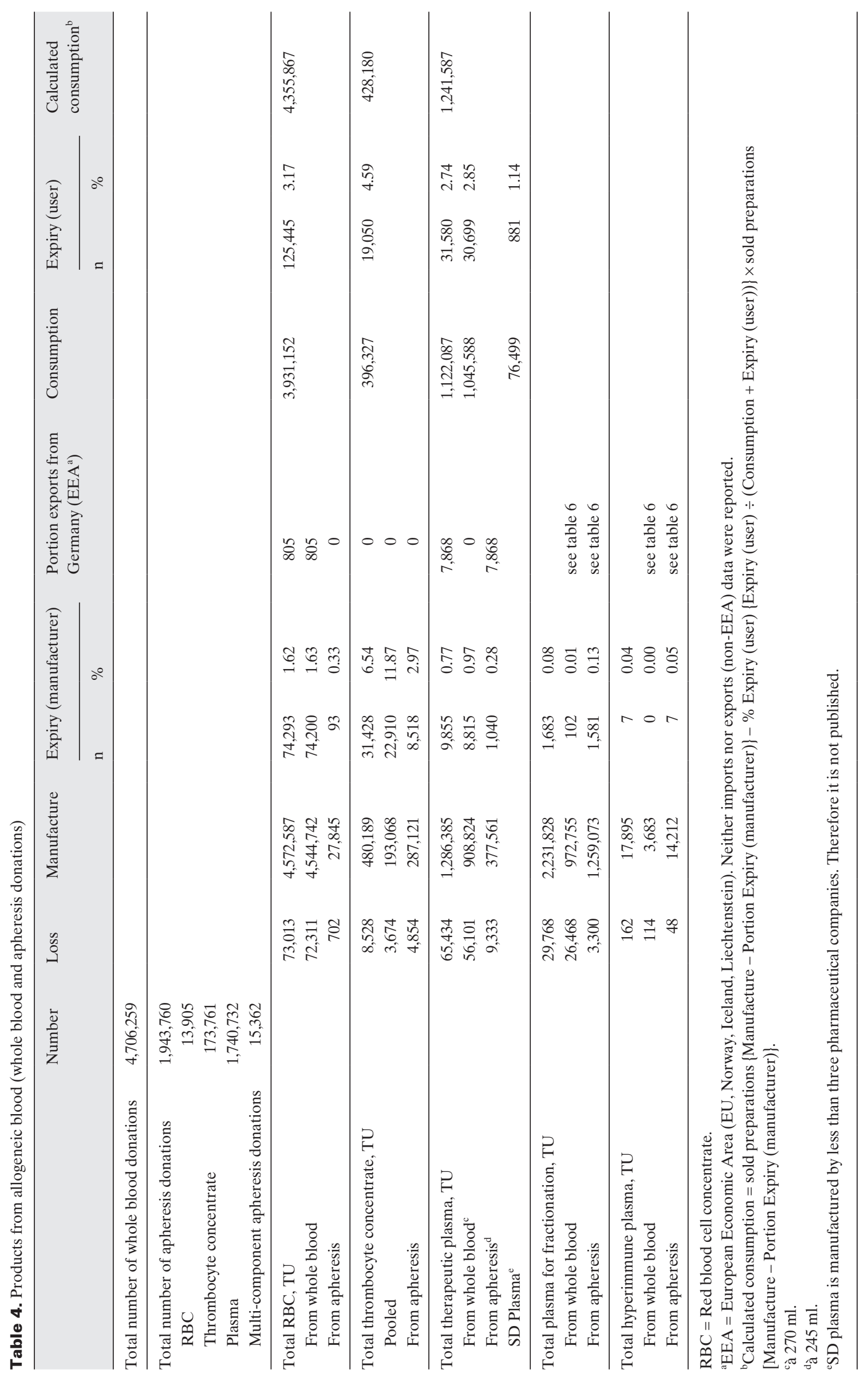




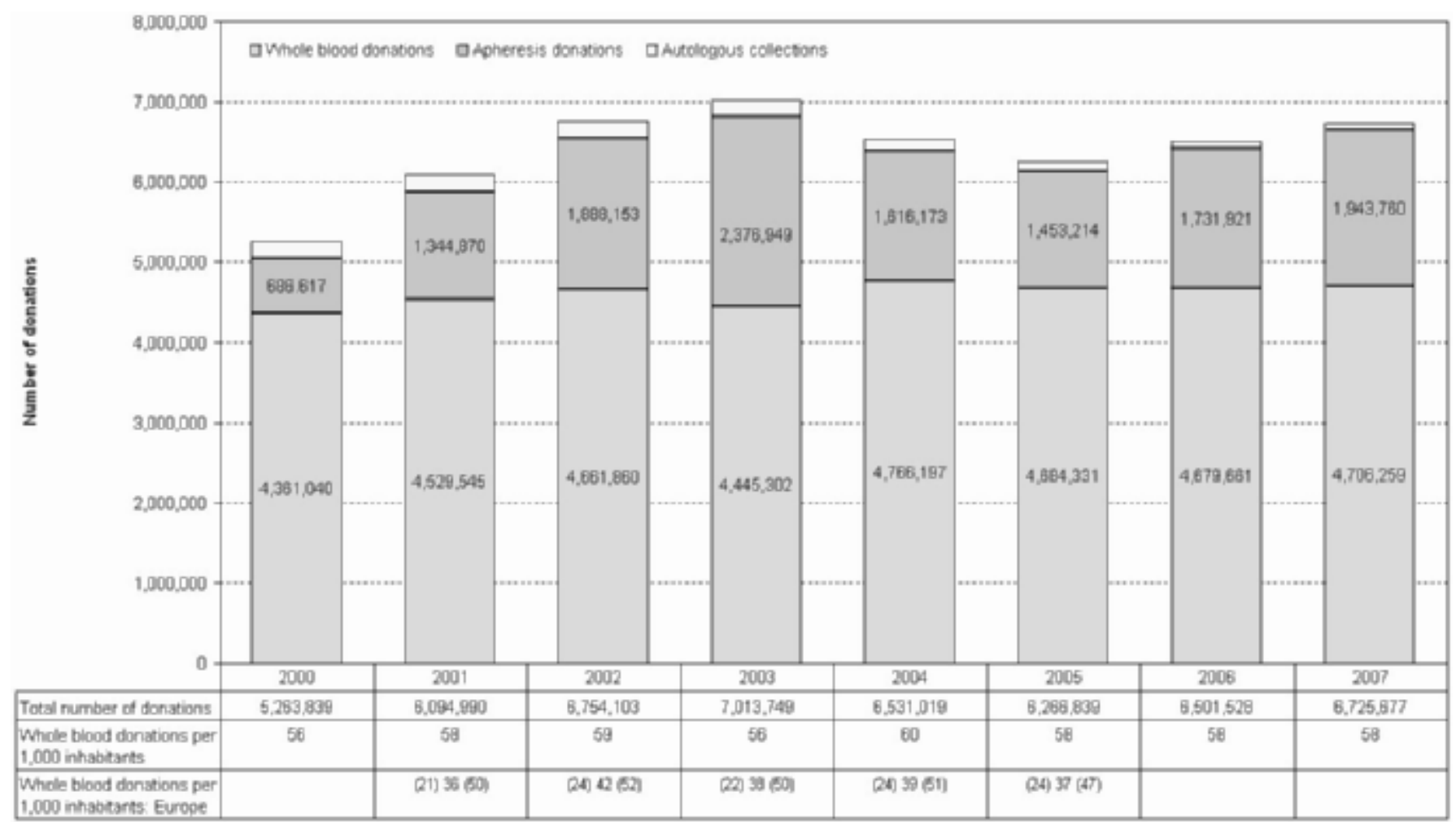

Fig. 1. Development of donations. Table: Number of whole blood donations per 1,000 inhabitants in Germany and, for comparison, in the member states of the Council of Europe from 2001 to 2005 specified as (25\% quartile) median ( $75 \%$ quartile).

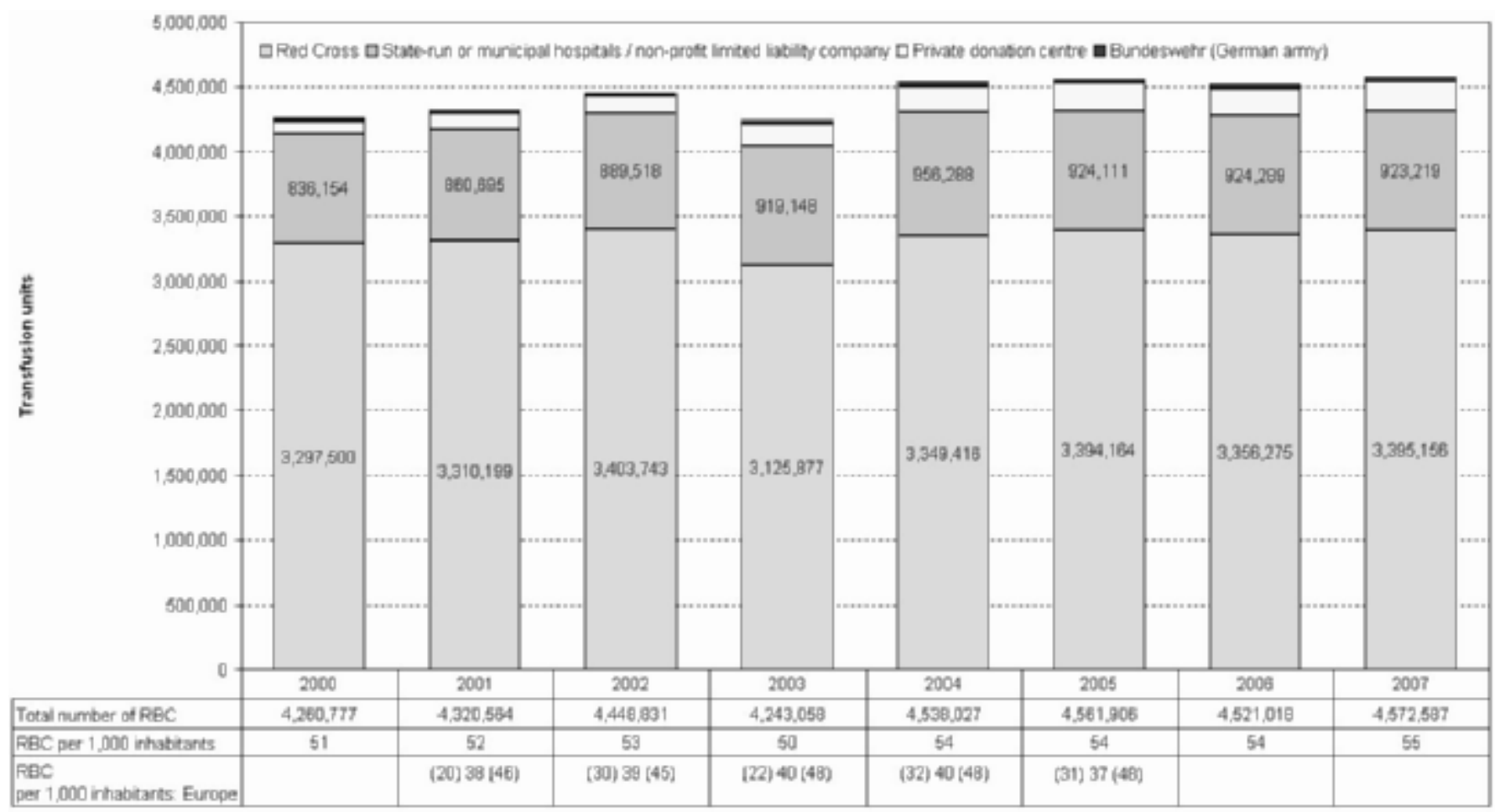

Fig. 2. Production of red blood cell concentrates from allogeneic blood. Table: Red blood cell concentrates per 1,000 inhabitants and, for comparison, in the member states of the Council of Europe from 2001 to 2005 specified as (25\% quartile) median (75\% quartile). 


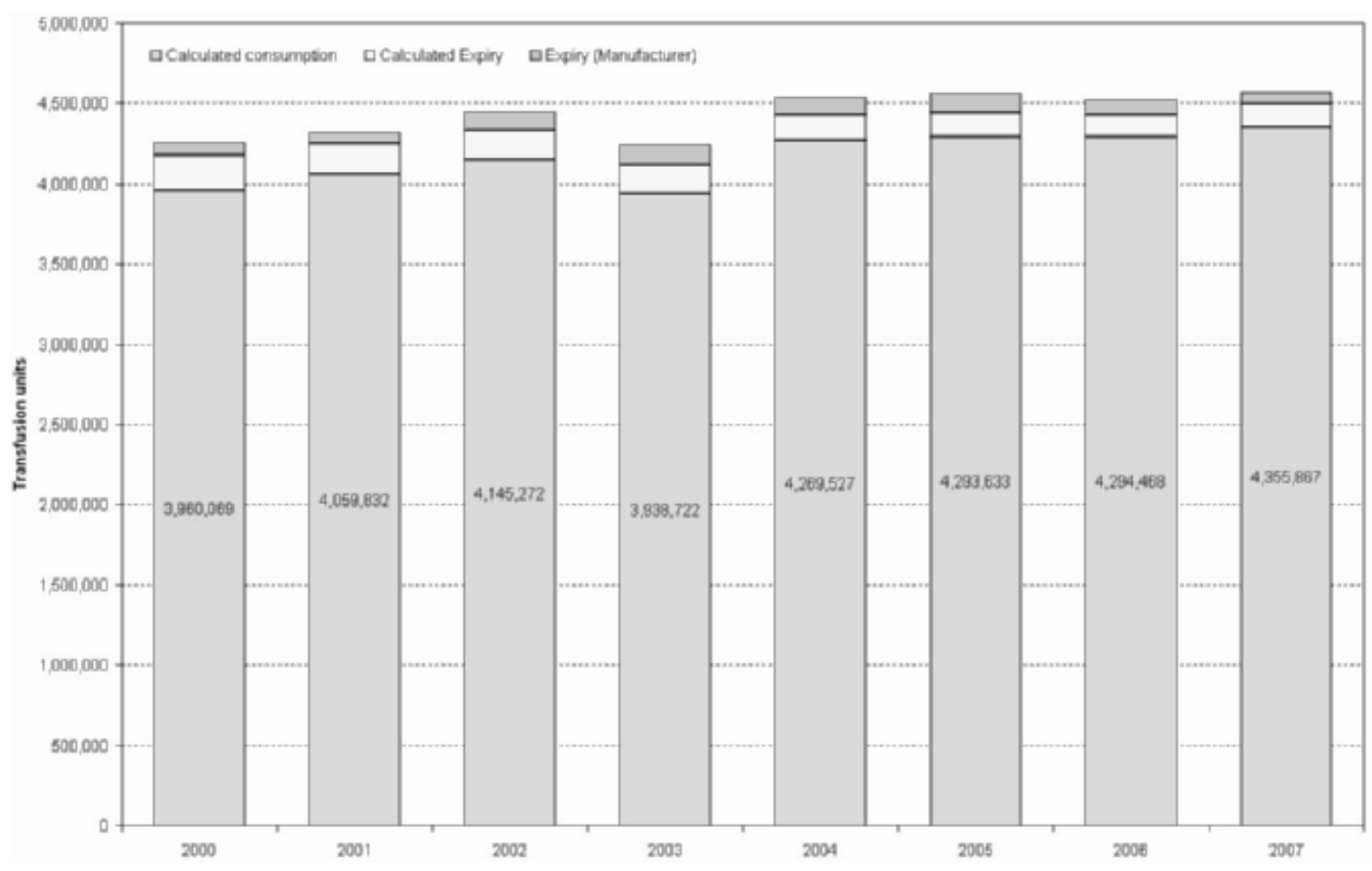

Fig. 3. Consumption of red blood cell concentrates from allogeneic blood: The calculated consumption and loss decline are highlighted. The total of these figures corresponds to the red blood cell concentrates sold. The total height of the column corresponds to the red blood cell concentrates produced (see also table 4).

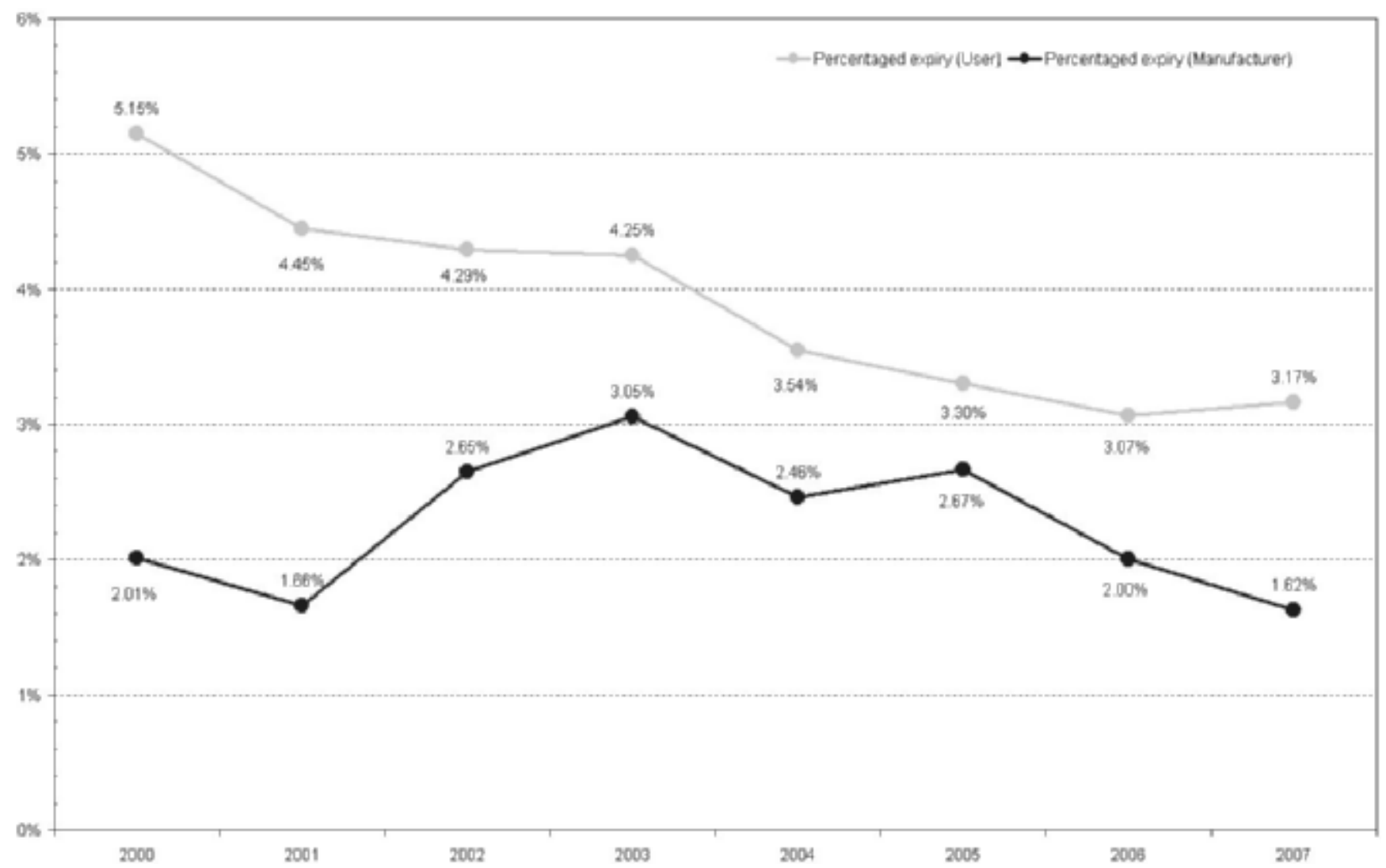

Fig. 4. Red blood cell concentrates from allogeneic blood: Reported amounts of lost red blood cell concentrates in \% among manufacturers and users. 
Table 5. Autologous blood and its components

\begin{tabular}{|c|c|c|c|c|c|c|c|}
\hline & \multirow[t]{2}{*}{ Number } & \multirow[t]{2}{*}{ Manufacture } & \multicolumn{2}{|c|}{ Portion expiry (manufacturer) } & \multirow[t]{2}{*}{ Consumption } & \multicolumn{2}{|c|}{ Expiry (user) } \\
\hline & & & $\mathrm{n}$ & $\%$ & & $\mathrm{n}$ & $\%$ \\
\hline Total number of autologous blood collections & 75,658 & & & & & & \\
\hline From whole blood & 72,241 & & & & & & \\
\hline From apheresis & 3,417 & & & & & & \\
\hline Left as whole blood for transfusion, TU & & 17,612 & 1,170 & 6.64 & 8,371 & 8,683 & 50.91 \\
\hline Total RBC & & 52,761 & 3,825 & 7.25 & 27,193 & 20,333 & 42.78 \\
\hline From whole blood & & 49,305 & 2,978 & 6.04 & & & \\
\hline From apheresis & & 3,456 & 847 & 24.51 & & & \\
\hline Total thrombocyte concentrate, TU & & 162 & 1 & 0.62 & 323 & 3 & 0.92 \\
\hline From whole blood & & 135 & 1 & 0.74 & & & \\
\hline From apheresis & & 27 & 0 & 0.00 & & & \\
\hline Total plasma, TU & & 53,945 & 3,895 & 7.22 & 29,243 & 18,320 & 38.52 \\
\hline From whole blood & & 47,249 & 3,095 & 6.55 & & & \\
\hline From apheresis & & 6,696 & 800 & 11.95 & & & \\
\hline
\end{tabular}

$\mathrm{RBC}=$ Red blood cell concentrate.

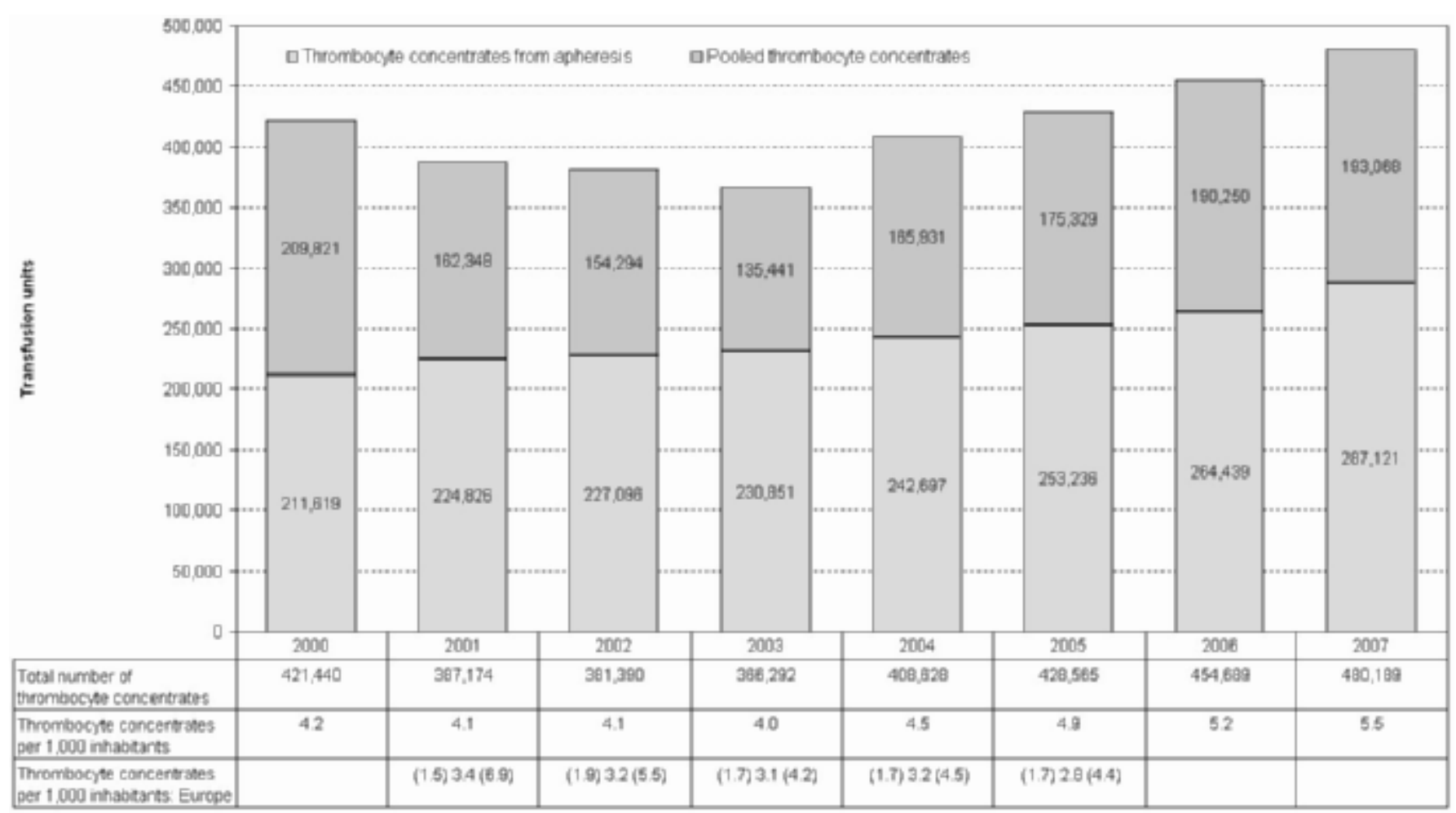

Fig. 5. Manufacture of platelet concentrates from allogeneic blood: Amounts of manufacture from whole blood and apheresis. Table: Platelet concentrates per 1,000 inhabitants and for comparison in the member states of the Council of Europe from 2001 to 2005 specified as (25\% quartile) median (75\% quartile).

culated as an approximate figure for the first time. For this purpose, it was assumed that i) all sold red blood cell concentrates were either transfused or lost at the consumer and that ii) the portion of red blood cell concentrates lost in the reporting institutions does not differ from the loss in the institutions which failed to report. The portion of lost red blood cell con- centrates on the consumer side was calculated from the data reported. The consumption was then calculated from the quantity of red blood cell concentrates sold $(4,498,294$ for 2007) minus the percentage loss in the health care facilities (3.1\% in 2007). The amount thus obtained for 2007 was 4.36 million red blood cell concentrates (table 4, fig. 3). 


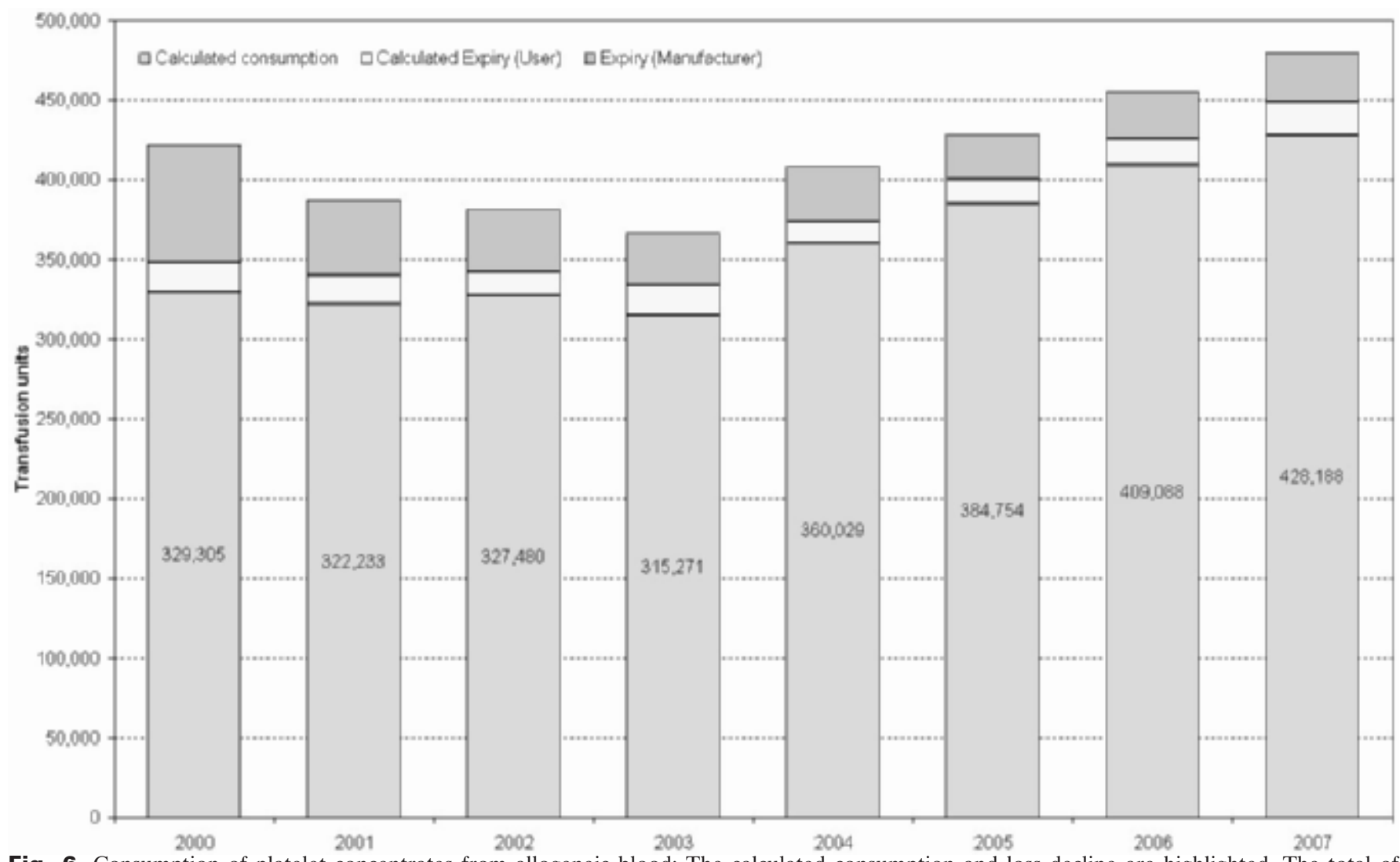

Fig. 6. Consumption of platelet concentrates from allogeneic blood: The calculated consumption and loss decline are highlighted. The total of these figures corresponds to the platelet concentrates sold. The total height of the column corresponds to the platelet concentrates produced (see also table 4).

Based on this calculation, the highest consumption of red blood cell concentrates since 2000 was recorded for 2007. This cannot only be ascribed to the number of red blood cell concentrates produced and sold, which has increased slightly, but also to the constant and significant decrease in the loss rate for the consumers $(\mathrm{p}<0.001)$ since 2000 from more than 5 to currently $3.2 \%$ (fig. 4 ). It would be welcomed if the decrease in the loss rate actually did reflect an economical use of these valuable products. The decrease could however be due to reporting errors since some major 'consumers' did not indicate a loss in 2007.

The percentage loss at the manufacturers did not show a significant trend, with rates between 1.7 and 3.1\% (fig. 4). Since the major portion of red blood cell concentrates is passed from the manufacturers to the consuming institutes after only few days, the logistic possibilities for minimising the loss at the manufacturer are already exploited.

In contrast to the declining loss of red blood cell concentrates from allogeneic blood donations at the consumer, the loss of autologous red blood cell concentrates is rising. The loss rate of $27.6 \%$ in 2000 , which was high anyway, rose to $42.8 \%$ in 2007. During the same period, the portion of autologous products, compared with the total amount of red blood cell concentrates produced in Germany, fell from 4 to $1.1 \%$ (table 5).

In 2007,55 red blood cell concentrates were available per
1,000 inhabitants in Germany. According to the latest unpublished report of the Council of Europe for 2005 [1], the median value is 37 red blood cell concentrates per 1,000 inhabitants throughout Europe, but with considerable fluctuations. If less than 20 red blood cell concentrates were manufactured per 1,000 inhabitants, this would indicate an insufficient availability of red blood cell concentrates. From this point of view, red blood cell concentrate supplies in Germany can be considered as assured. Considering the comparatively high per capita availability, it should be possible to bridge short-term gaps in the supplies by prioritising the use without running the risk of creating life-threatening situations for the patients - providing other factors such as an influenza pandemic will not lead to an acute extreme shortage.

\section{Platelet Concentrates}

Since 2003, the manufacture of platelet concentrates has increased by approximately $25,000 \mathrm{TU}$ to more than 475,000 units in the reporting year. The increase of $5.6 \%$ compared with 2006 can almost exclusively ascribed to the increased manufacture of apheresis platelet concentrates (table 4, fig. 5). In Europe, the mean portion of apheresis platelet concentrates is $35 \%$ [1]. Only in 7 of altogether 33 European countries do more than $50 \%$ of the platelet concentrates originate from apheresis, as is the case in Germany. 


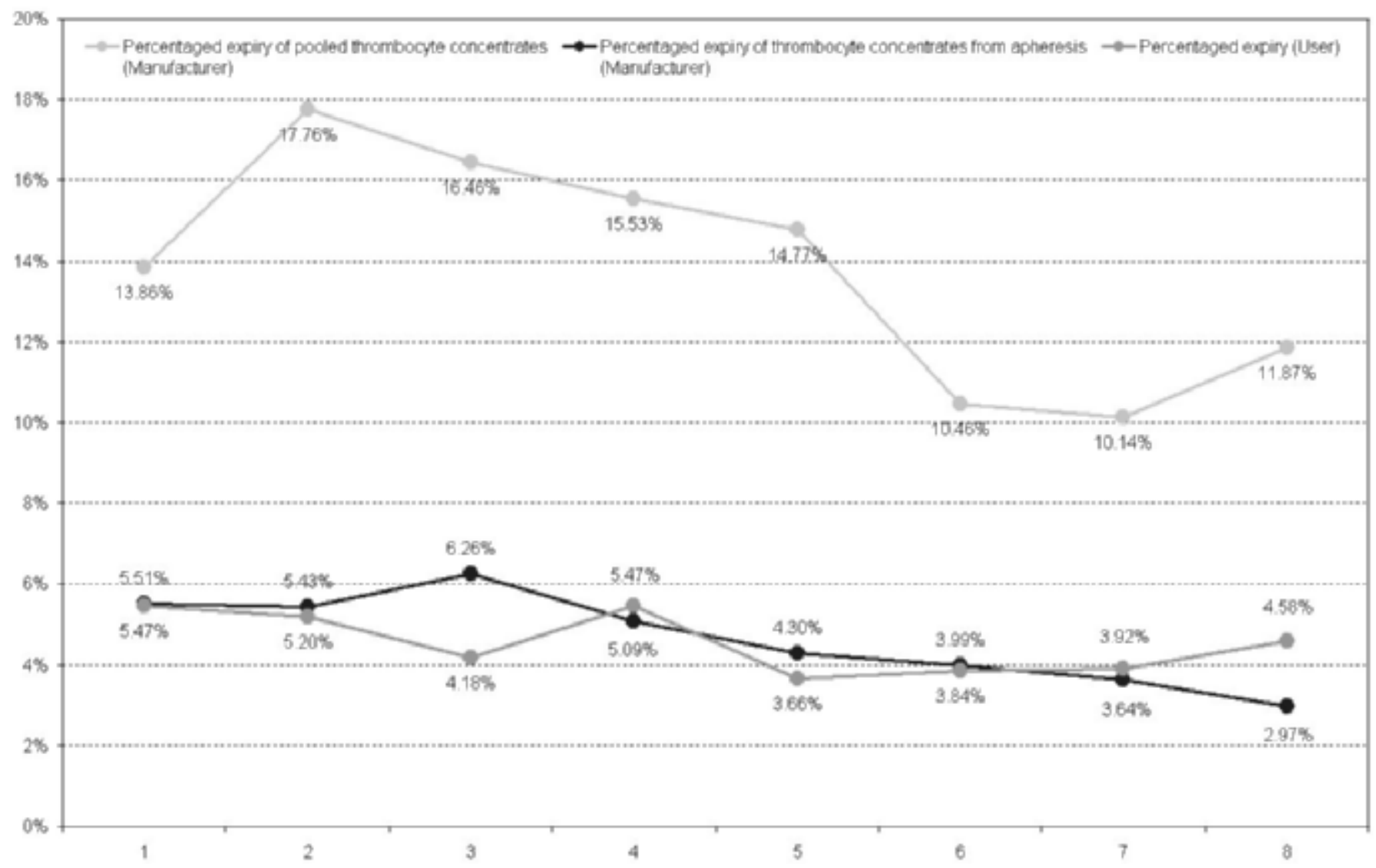

Fig. 7. Platelet concentrates from allogeneic blood: Portions reported of expired platelet concentrates in $\%$ among manufacturers and users.

The consumption of platelet concentrates reported for 2007 has increased by almost 33,000 TU compared with 2006. Similarly to red blood cell concentrates, however, there is also a discrepancy between platelet concentrates reported as sold and those reported by the consuming institutions (transfused plus lost), even though this 'gap' caused by missing reports has fortunately decreased considerably, with only $7 \%$ in 2007 compared with $10 \%$ in the previous year. To obtain more plausible figures for the real consumption, the latter was calculated as an approximate value, as was done for red blood cell concentrates. According to this calculation, 428,188 platelet concentrates were consumed in the reporting year (fig. 6). Approximately 5.5 platelet concentrates per 1,000 inhabitants were provided by the blood donation centres. For comparison while in European countries in median 2.75 [3] platelet concentrates were sold in 2005 , in the same year this figure was 4.9 platelets per 1,000 inhabitants for Since 2003, manufacturing figures and the consumption reported for platelet concentrates have increased steadily which can be interpreted to indicate that production rates have so far been able to keep up with the increased demand. From that point of view, availability of platelet concentrates can be regarded as good.

In the health care facilities, $3.7-5.5 \%$ of the platelet concentrates were lost between 2000 and 2007 (fig. 7). According to reports from a total of 1,051 hospitals that transfused platelet concentrates, in 2007 a total of $4.7 \%$ were lost. Only apheresis platelet concentrates showed a loss rate at the manufacturer in the same order of magnitude. The loss rate for pool platelet concentrates, on the other hand, was markedly higher. This difference is not unexpected since apheresis platelet concentrates are predominantly produced by institutes at maximum care hospitals which can react to the current demand in a targeted manner. In addition, apheresis platelet concentrates are often produced for a particular purpose and occasion. Besides, the higher price, might affect the lower loss rate.

\section{Plasma for Transfusion}

From 2000 to 2003, the number of produced TU of plasma for transfusion decreased by $25 \%$. During the same period, the plasma quantity assigned to fractionation increased by $39 \%$, which is the highest value during the observation period (figs. 8 and 9).

Between 2003 and 2006, the amount of single units of therapeutic plasma showed a mean of slightly more than 1.1 million TU. In the reporting year, the number of units for this product was more than 1.2 million TU for the first time after a long period (fig. 8). 


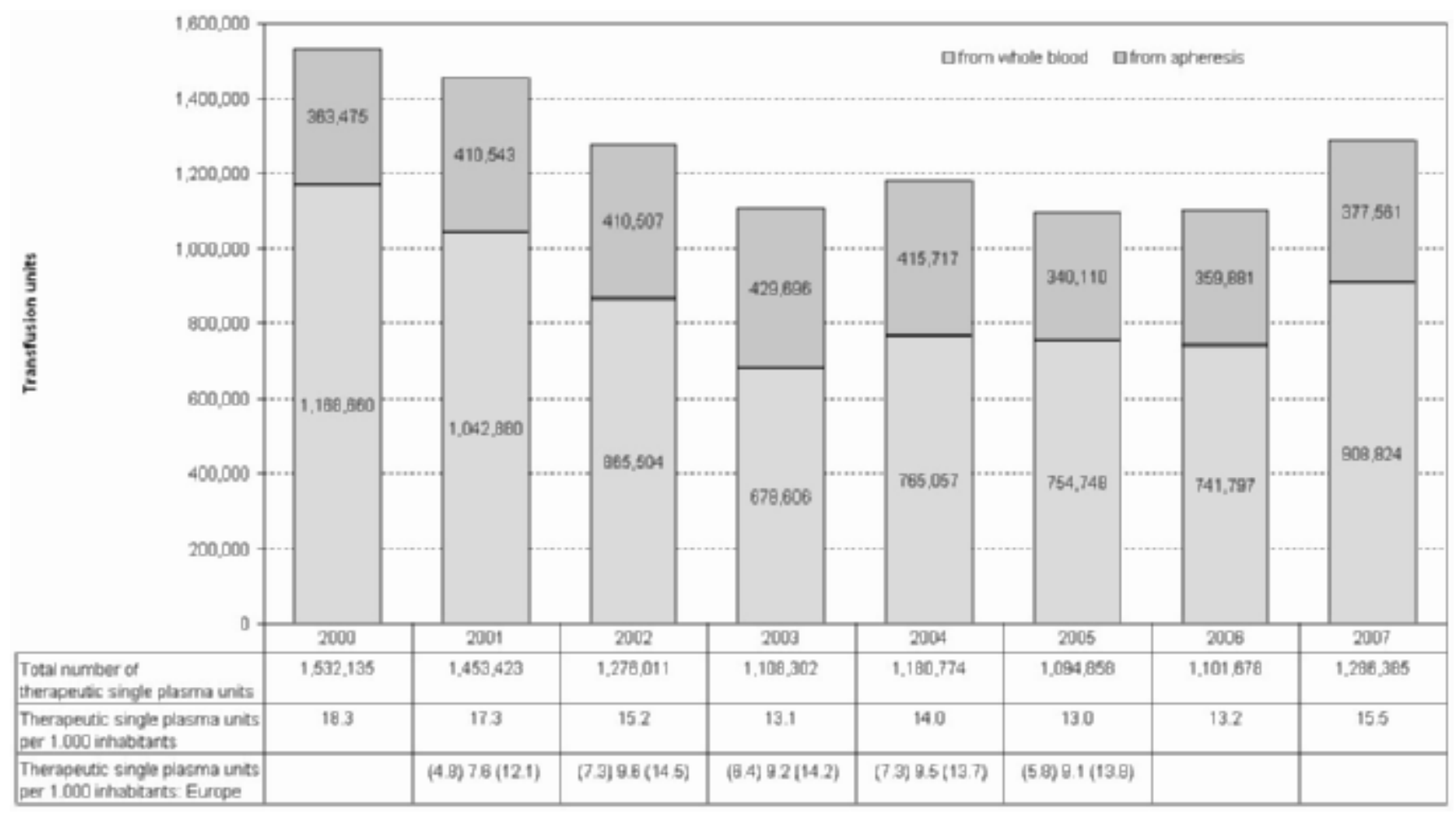

Fig. 8. Therapeutic single plasma sample from allergenic blood: Portions of manufacture accounted for by whole blood and apheresis. Table: TU per 1,000 inhabitants and for comparison in the member states of the Council of Europe from 2001 to 2005 specified as $(25 \%$ quartile) median ( $75 \%$ quartile).

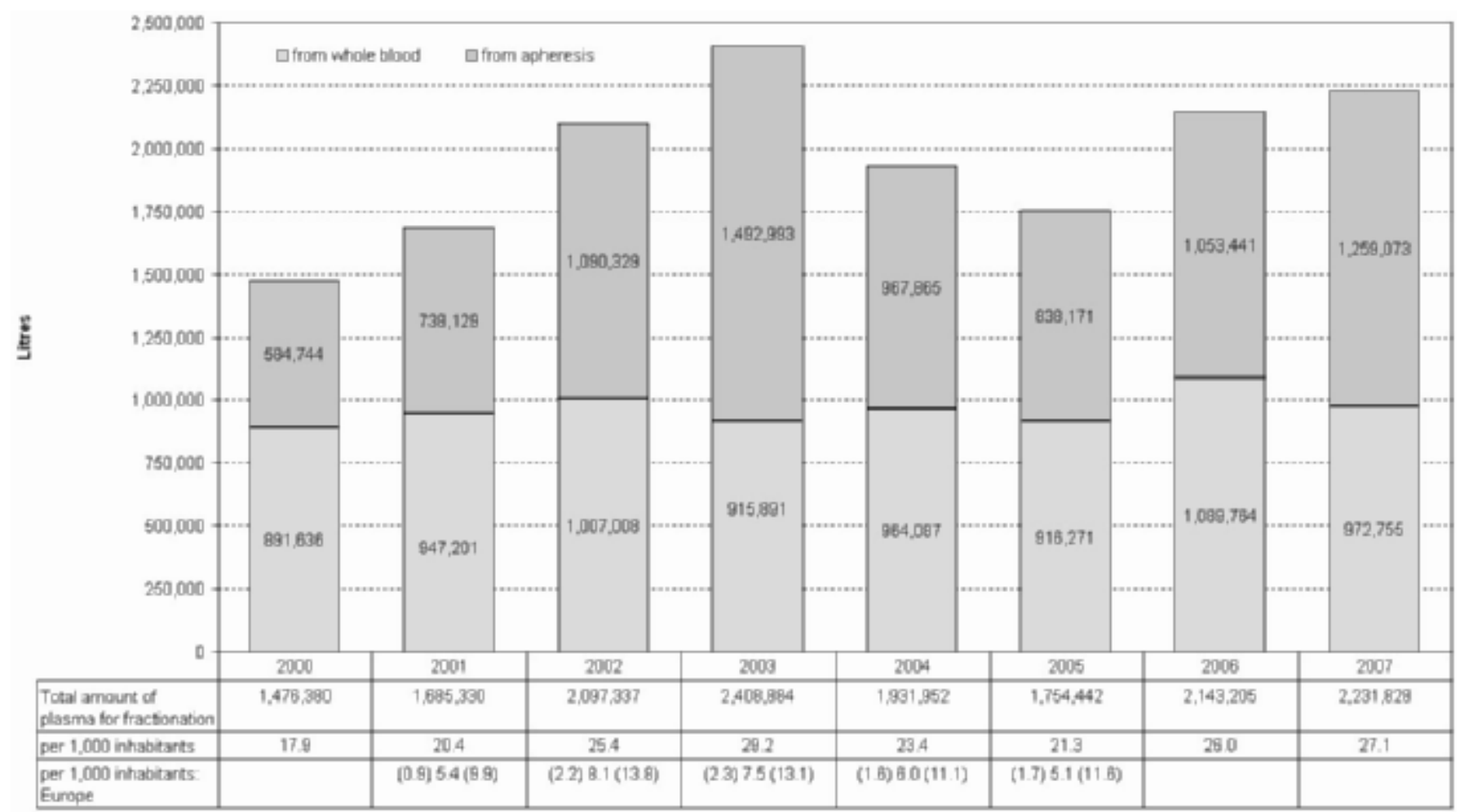

Fig. 9. Plasma for fractionation: Amounts from whole blood and apheresis donations. Table: 1 1/1,000 inhabitants in Germany and, for comparison, in the member states of the Council of Europe from 2001 to 2005 specified as (25\% quartile) median (75\% quartile). 


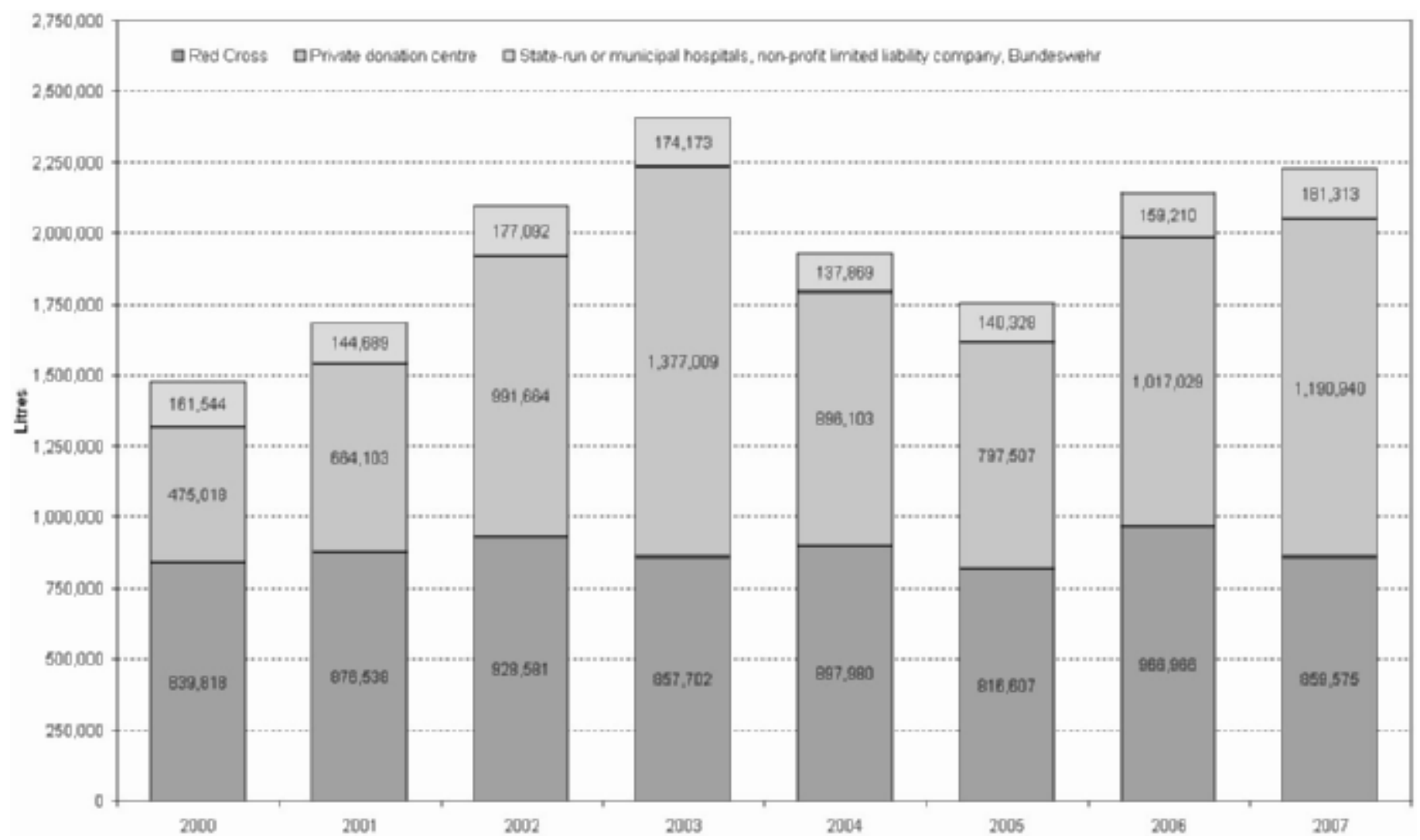

Fig. 10. Plasma for fractionation: Portions of the manufacturers compared with the total amount.

Similarly to the red blood cell and platelet concentrates, the reported consumption and loss of plasma for transfusion is approximately $10 \%$ lower than the quantity sold by the manufacturers. The consumption reported fluctuated only slightly during the period from 2000 to 2007 , i.e. between 1.05 and 1.17 million TU. Since 2007, SD plasma is no longer manufactured in Germany. The portion of SD plasma compared with the plasma consumption reported in total decreased from $9.7 \%$ in 2006 to $6.7 \%$ in 2007 .

According to the figures reported, the loss rate for therapeutic single plasma and for SD plasma at the user has been a constant rate of $3.2 \%$ and $1.2 \%$ respectively since 2000 . The difference may be affected by differences in prices, or else, by the fact that SD plasma is predominantly sold as universal plasma (AB plasma).

\section{Plasma for Fractionation}

No other country in Europe collects as much plasma for fractionation as Germany. Compared with 2006, the quantity rose by $4 \%$ to a total of 2.2 million 1 in 2007, the second highest value after the 'boom year' 2003. This is equivalent to 271 plasma per 1,000 inhabitants (fig. 9). As a comparison, in Europe, in median 51 were collected in 2005; in Germany, the figure was 211 per 1,000 inhabitants. This constituted the highest per-capita quantity in Europe in 2005. Only Germany, Belgium, the Netherlands, Sweden, and Luxembourg of the
35 European countries recorded, showed a figure of more than 151 per 1,000 inhabitants [1].

As in the past few years, private plasmapheresis centres, including plasmapheresis centres of the plasma processing industry, accounted for the highest portion of this type of plasma collection in 2007, with 53\%. The institutes of the Red Cross provided $38.5 \%$ while the government and local authority institutions, and those classified as non-profit-making accounted for the remaining $8.1 \%$ (fig. 10). Fluctuations in the total volume for plasma for fractionation are solely caused by the amount of plasma produced by plasmapheresis during the observation period 2000-2007. During the same period, the portion of plasma for fractionation from whole blood was constantly at around 1 million 1/year (fig. 9). Despite the fluctuations observed, plasma for fractionation in Germany today is derived mainly from plasmapheresis, contrary to the year 2000. The report by the Council of Europe for the years between 2001 and 2005, however, indicates a mean of $28 \%$ throughout Europe [1].

Plasma for fractionation is sold across countries, as required. Thus, 2.25 million 1 were produced in Germany in 2007; at the same time, however, 1.83 million 1 were exported and 1.01 million 1 imported. Referred to the amount produced in 2007, the remainder amounted to a net value of 1.41 million $1(63 \%)$ in Germany. 1.29 million 1 were fractionated in Germany (table 6 and fig. 11). 
Table 6. Plasma for fractionation

\begin{tabular}{lrrrrrrrrr}
\hline & Collection & Loss & $\begin{array}{l}\text { Portion expiry } \\
\text { (manufacturer) }\end{array}$ & $\begin{array}{l}\text { Portion } \\
\text { exports } \\
\text { (EEA) }\end{array}$ & $\begin{array}{l}\text { Portion ex- } \\
\text { ports } \\
\text { (non-EEA) }\end{array}$ & $\begin{array}{l}\text { Total } \\
\text { exports }\end{array}$ & $\begin{array}{l}\text { Imports } \\
\text { (non-EEA) }\end{array}$ & $\begin{array}{l}\text { On the } \\
\text { German } \\
\text { market }\end{array}$ & $\begin{array}{l}\text { Fractionation } \\
\text { in Germany }\end{array}$ \\
\hline $\begin{array}{l}\text { Total plasma for } \\
\text { fractionation, 1 }\end{array}$ & $2,231,828$ & 29,768 & 1,683 & 352,366 & $1,481,341$ & $1,833,707$ & $1,015,199$ & $1,413,320$ & $1,385,183$ \\
$\quad \begin{array}{l}\text { From whole blood } \\
\text { From apheresis }\end{array}$ & 972,755 & 26,468 & 102 & 145,783 & 158,587 & 304,370 & 0 & 668,385 & 112,283 \\
\hline $\begin{array}{l}\text { Total hyperimmune } \\
\text { plasma, }\end{array}$ & $1,259,073$ & 3,300 & 1,581 & 206,583 & $1,322,754$ & $1,529,337$ & $1,015,199$ & 744,935 & $1,272,900$ \\
\hline
\end{tabular}

EEA = European Economic Area (EU, Norway, Iceland, Liechtenstein). No imports from EEA were reported.

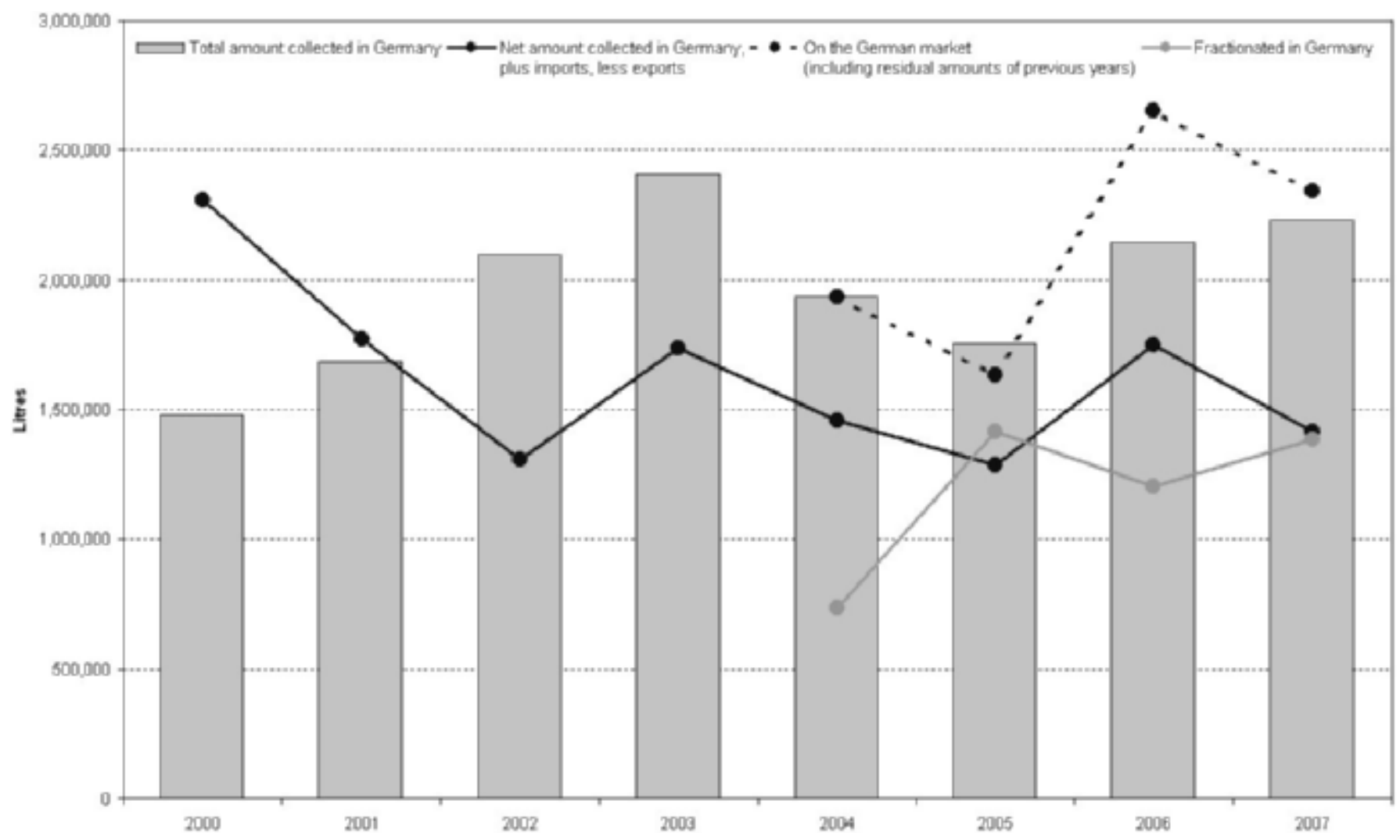

Fig. 11. Plasma for fractionation: Columns show the amounts collected in Germany annually. The continuous line shows a year's net production including import and export. In addition, the amount of plasma fractionated in Germany from 2004 to 2007 is highlighted in grey. The dashed line corresponds to the calculated amount available on the German market taking into account the imports, exports and the calculated residual amounts of previous years.

Since 2004, in addition to the collection, imports, and exports, the amount of plasma fractionated in Germany has been recorded. The evaluation of these figures shows that the amount of plasma available in Germany year by year by far exceeds the amount assigned to fractionation. This supposedly stored remainder is growing constantly. Whether or not reserves really are available in such amounts cannot be judged (fig. 11).

\section{Plasma Proteins}

In order to judge better the degree of self-sufficiency for plasma derivatives and recombinant medicinal products for the treatment of patients with haemostasis disorders, investigations were made on the amount of medicinal products sold and manufactured in Germany in 2004. The evaluation of the figures reported on the manufacture, sale, and consumption does not show a shortage of such products in Germany. Even 
Table 7. Plasma derivatives: comparison of manufacture, amount sold on the German market and consumption in Germany

\begin{tabular}{|c|c|c|}
\hline Product & $\begin{array}{l}\text { Manufacture in } \\
\text { Germany relating } \\
\text { to consumption }\end{array}$ & $\begin{array}{l}\text { Amount sold on the } \\
\text { German market relating } \\
\text { to consumption }\end{array}$ \\
\hline$\alpha_{1}$-Proteinase inhibitor & - & $\uparrow$ \\
\hline $\mathrm{C} 1$ inactivator & $\uparrow$ & $\uparrow$ \\
\hline Antithrombin III & $\uparrow$ & \pm \\
\hline Protein $\mathrm{C}$ & - & $\uparrow$ \\
\hline Coagulation factor VIII from plasma & $\uparrow$ & $\uparrow$ \\
\hline Coagulation factor VIII recombinant & - & $\uparrow$ \\
\hline Coagulation factor IX from plasma & $\downarrow$ & $\uparrow$ \\
\hline Coagulation factor IX recombinant & - & $\uparrow$ \\
\hline Coagulation factor VII & - & \pm \\
\hline Coagulation factor VIIa recombinant & - & - \\
\hline Prothrombin complex (PPSB) & $\downarrow$ & $\uparrow$ \\
\hline Coagulation factor VIII inhibitor bypass & - & $\uparrow$ \\
\hline Coagulation factor XIII & $\uparrow$ & \pm \\
\hline Fibrinogen & $\uparrow$ & $\downarrow$ \\
\hline Fibrin sealants & $\uparrow$ & $\uparrow$ \\
\hline Immunoglobulins, normal & $\uparrow$ & $\uparrow$ \\
\hline Specific immunoglobulins (anti-D) & - & \pm \\
\hline Specific immunoglobulins & $\uparrow$ & $\downarrow$ \\
\hline Biseko & $\uparrow$ & $\uparrow$ \\
\hline Human albumin & $\uparrow$ & $\uparrow$ \\
\hline
\end{tabular}

if a product was not manufactured in Germany, the demand could be met by imports.

The data on the products 'fibrinogen' and 'specific immunoglobulins' are not plausible. The quantity manufactured in Germany could have met the demand sufficiently without exports. According to the figures reported, however, a much higher quantity was consumed in Germany than was sold on the German market. Since this phenomenon persists throughout the years observed, it cannot be due to the sale of the stock from the previous year. The discrepancy referenced may be explained by re-imports not recorded in reports conforming to Section 21 TFG.

On the other hand, it is remarkable that only $4.7 \%$ of the quantity sold of the product ' $\alpha_{1}$-proteinase inhibitor' was reported as consumed (tables 7,8).

\section{Peripheral Blood Stem Cells}

The number of stem cell products manufactured from apheresis rose from just under 9,000 in 2000 to around 12,000 in 2007. The number of autologous products has been a mean of 6,800 per year ever since recording was started. The number of allogeneic transplantations increased from around 2,000 to roughly 4,700 in 2007 (fig. 12).

A total of 4,861 transplants from allogeneic donations were available in 2007. 4,682 of these transplants were manufactured in Germany and 179 were imported. At the same time,
1,810 transplants could be exported, which is almost the same amount as was used for transplantation in Germany (table 9). Stem cell donations are thus obviously so well organised in Germany that the demand can almost exclusively be met by donations from Germany.

\section{Stem Cells from Cord Blood}

Since 2000, the number of stored products per year has more than doubled to around 13,000 in 2007 - only around one sixth of these products are allogeneic transplants. There is no equivalent to the figure of more than 10,000 autologous products stored in the reporting year on the consumption side, but there were at least 15 transplantations per roughly 2600 allogeneic products (table 10).

\section{Data on Patients with Congenital Haemostasis Disorders}

The data on patients with haemophilia $\mathrm{A}$ and $\mathrm{B}$ requiring treatment were contradictory, particularly at the beginning of their collection. Thus, the strong decline in 2002 can hardly be ascribed to the fact that during this period a large part of patients did not need treatment (fig. 14). In 2007, too, the numbers of 2,782 patients reported with haemophilia A (table 11) and 526 with haemophilia B (table 12) are much lower than the total number of patients estimated in Germany, in spite of the increased response rate of $81 \%$ on the part of the known haemophilia treaters (table 3 ). For comparison, a report from 


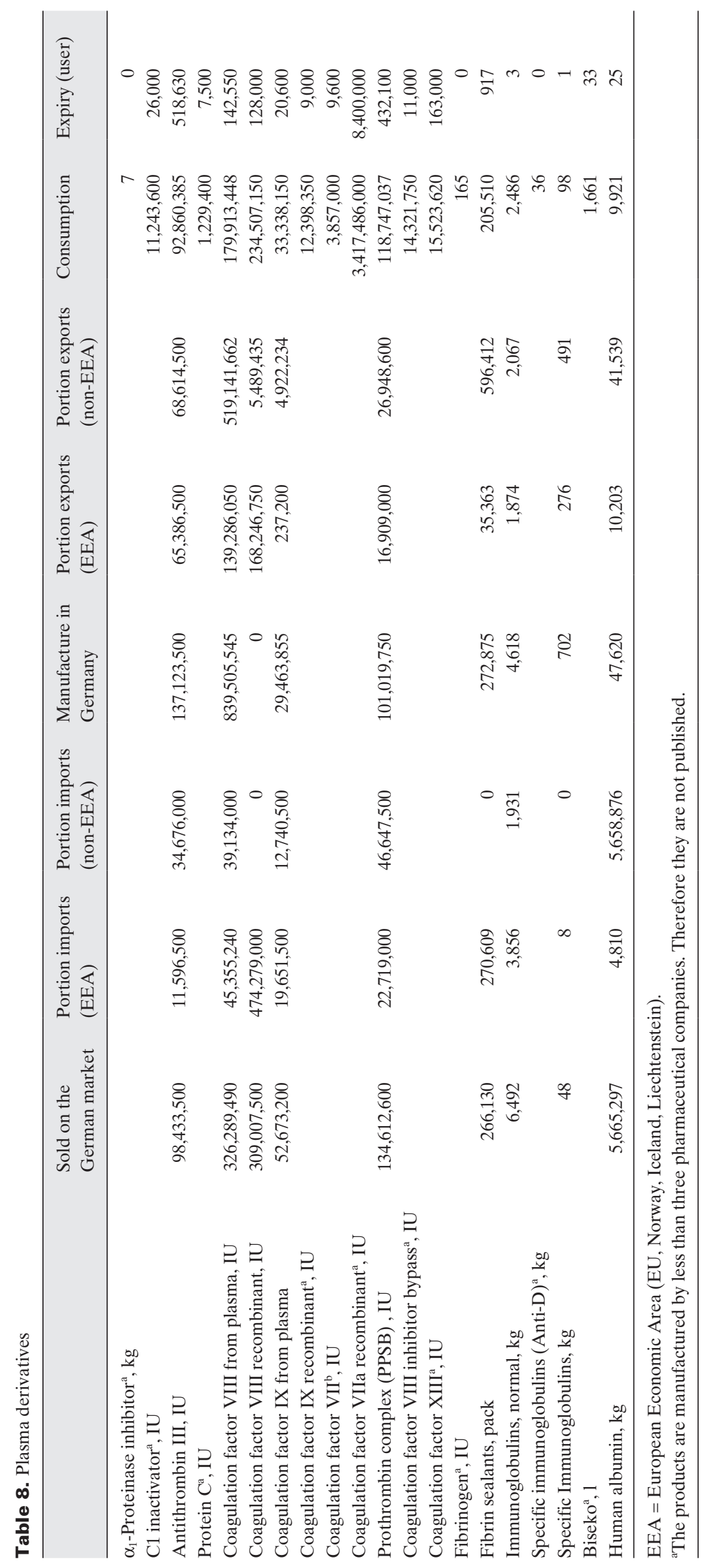




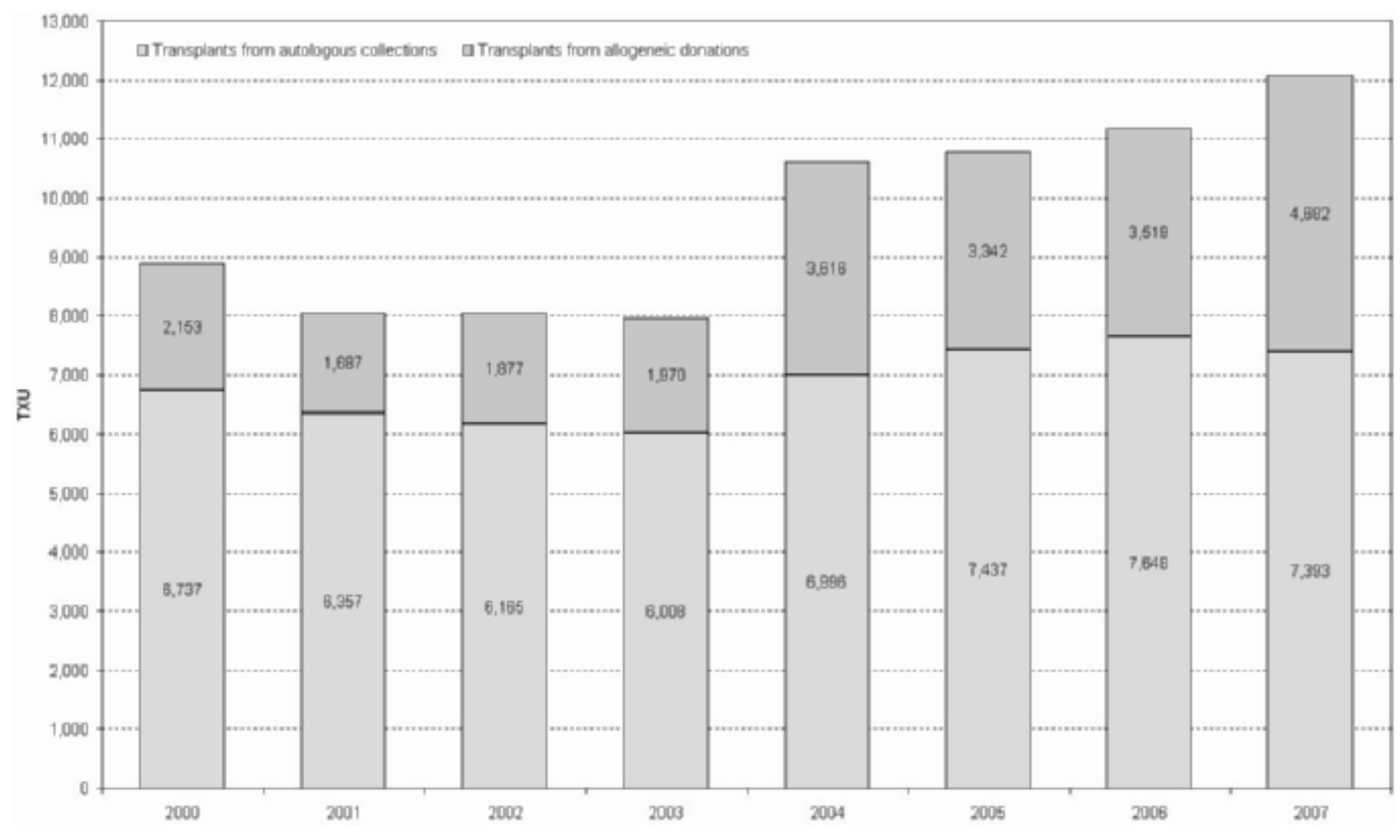

Fig. 12. Blood stem cells from apheresis: Amounts from allogeneic donations and autologous collections. TXU = individual dose for a transplant which can consist of several apheresis donations/bags.

Table 9. Peripheral blood stem cells

\begin{tabular}{lcc}
\hline & \multicolumn{2}{c}{ Peripheral blood stem cells } \\
\cline { 2 - 3 } & autologous & allogeneic \\
\hline Number of separations & 5,704 & 4,678 \\
Number of donors & 3,365 & 3,900 \\
Manufacture, TXU & 7,393 & 4,682 \\
Portion expiry (manufacturer), TXU & 189 & 19 \\
Portion exports (EEA), TXU & 0 & 1,034 \\
Portion exports (non-EEA), TXU & 1 & 776 \\
Imports (EEA), TXU & 0 & 112 \\
Imports (Non-EEA), TXU & 1 & 67 \\
Loss (manufacturer), TXU & 65 & 14 \\
Number of grafts & 3,072 & 2,027 \\
\hline
\end{tabular}

EEA = European Economic Area (EU, Norway, Iceland, Liechtenstein); TXU = individual dose for a transplant which can consist of several apheresis donations/bags.

the UK [4] can be used which refers to 6,500 patients with haemophilia A and 1,200 patients with haemophilia B. This discrepancy can be explained by still missing reports as well as by the fact that only patients requiring treatment are reported, but also by the fact that not all data on haemophilia treaters have been collected yet or the reports are incomplete.
Table 10. Stem cells from cord blood

\begin{tabular}{lcc}
\hline & \multicolumn{2}{c}{ Stem cells from cord blood } \\
\cline { 2 - 3 } & autologous & allogeneic \\
\hline Manufacture, TXU & 10,313 & 2,657 \\
Portion exports (EEA), TXU & 0 & 65 \\
Portion exports (Non-EEA), TXU & 0 & 43 \\
Imports (EEA), TXU & 344 & 2 \\
Imports (non-EEA), TXU & 0 & 0 \\
Loss (manufacturer), TXU & 482 & 1,800 \\
Number of grafts & 0 & 15 \\
\hline
\end{tabular}

$\mathrm{EEA}=$ European Economic Area (EU, Norway, Iceland, Liechtenstein); TXU = individual dose for a transplant which can consist of several apheresis donations/bags.

Nevertheless, the numbers meanwhile show a clear trend towards consumption of recombinant factor VIII and IX concentrates in comparison to factor concentrates from human plasma.

The consumption of recombinant factor VIII was higher than the consumption of medicinal products from human plasma in 2007 , accounting for $55 \%$. On the other hand, factor VIII from human plasma was predominantly used for immune tolerance treatment in patients with inhibitors; the rate among 
Table 11. Haemophilia A patients

\begin{tabular}{|c|c|c|c|c|c|}
\hline & $\begin{array}{l}\text { Number of } \\
\text { patients }\end{array}$ & $\begin{array}{l}\text { Consumption } \\
\text { plasma-derived } \\
\text { coagulation } \\
\text { factor VIII, IU }\end{array}$ & $\begin{array}{l}\text { Consumption } \\
\text { recombinant } \\
\text { coagulation } \\
\text { factor VIII, IU }\end{array}$ & $\begin{array}{l}\text { Consumption } \\
\text { coagulation factor } \\
\text { VIII inhibitor } \\
\text { bypass, IU }\end{array}$ & $\begin{array}{l}\text { Consumption } \\
\text { recombinant } \\
\text { coagulation } \\
\text { factor VIIa, IU }\end{array}$ \\
\hline \multirow{4}{*}{$\begin{array}{l}\text { Children and adolescents }{ }^{\mathrm{a}} \text { without inhibitory bodies } \\
\text { Portion with mild }{ }^{\mathrm{b}} \text { hemophilia A } \\
\text { Portion with haemophilia A of medium severity } \\
\text { Portion with severe }^{\mathrm{d}} \text { haemophilia A }\end{array}$} & 799 & $39,673,900$ & $70,445,750$ & 0 & $13,980,000$ \\
\hline & 160 & $4,020,400$ & $2,694,500$ & 0 & 0 \\
\hline & 103 & $1,384,000$ & $6,647,500$ & 0 & 0 \\
\hline & 536 & $34,269,500$ & $61,103,750$ & 0 & $13,980,000$ \\
\hline \multirow{3}{*}{$\begin{array}{l}\text { Children and adolescents }{ }^{\mathrm{a}} \text { with inhibitory bodies } \\
\text { Portion low responder } \\
\text { Portion high responder }{ }^{\mathrm{f}}\end{array}$} & 48 & $35,124,450$ & $1,399,000$ & $15,718,250$ & $336,580,000$ \\
\hline & 10 & $5,405,000$ & 547,500 & 12,000 & $9,720,000$ \\
\hline & 38 & $29,719,450$ & 851,500 & $15,706,250$ & $326,860,000$ \\
\hline Adults without inhibitory bodies & 1,885 & $119,150,050$ & $181,069,550$ & 20,000 & $42,128,000$ \\
\hline Portion with mild ${ }^{\mathrm{b}}$ haemophilia A & 326 & $4,877,050$ & $8,838,722$ & 0 & 0 \\
\hline Portion with haemophilia A of medium severity ${ }^{\mathrm{c}}$ & 303 & $11,516,583$ & $15,777,587$ & 0 & $35,648,000$ \\
\hline Portion with severe ${ }^{\mathrm{d}}$ haemophilia A & 1,256 & $102,756,417$ & $156,453,241$ & 20,000 & $6,480,000$ \\
\hline Adults with inhibitory bodies & 50 & $12,788,500$ & $2,813,000$ & $8,114,000$ & $807,160,000$ \\
\hline Portion low responder ${ }^{\mathrm{e}}$ & 13 & 387,500 & $1,080,000$ & 542,000 & $29,640,000$ \\
\hline Portion high responder ${ }^{\mathrm{f}}$ & 37 & $12,401,000$ & $1,733,000$ & $7,572,000$ & $777,520,000$ \\
\hline Total children and adolescents ${ }^{\mathrm{a}}$ & 847 & $74,798,350$ & $71,844,750$ & $15,718,250$ & $350,560,000$ \\
\hline Total adults & 1,935 & $131,938,550$ & $183,882,550$ & $8,134,000$ & $849,288,000$ \\
\hline Grand total & 2,782 & $206,736,900$ & $255,727,300$ & $23,852,250$ & $1,199,848,000$ \\
\hline \multicolumn{2}{|l|}{$\begin{array}{l}{ }^{\mathrm{a}} \text { Up to age } 18 \text { years. } \\
{ }^{\mathrm{e}}<5 \text { Bethesda units } / \mathrm{ml} .\end{array}$} & \multicolumn{2}{|c|}{${ }^{c} 2-5 \%$ residual activity. } & \multicolumn{2}{|c|}{${ }^{\mathrm{d}}<2 \%$ residual activity. } \\
\hline
\end{tabular}

Table 12. Haemophilia B patients

\begin{tabular}{|c|c|c|c|c|c|}
\hline & $\begin{array}{l}\text { Number of } \\
\text { patients }\end{array}$ & $\begin{array}{l}\text { Consumption } \\
\text { plasma-derived } \\
\text { coagulation } \\
\text { factor IX, IU }\end{array}$ & $\begin{array}{l}\text { Consumption } \\
\text { recombinant } \\
\text { coagulation } \\
\text { factor IX, IU }\end{array}$ & $\begin{array}{l}\text { Consumption } \\
\text { coagulation factor } \\
\text { VIII inhibitor } \\
\text { bypass IU }\end{array}$ & $\begin{array}{l}\text { Consumption } \\
\text { recombinant } \\
\text { coagulation } \\
\text { factor VIIa, IU }\end{array}$ \\
\hline Children and adolescents ${ }^{\mathrm{a}}$ without inhibitory bodies & 180 & $15,408,900$ & $6,654,500$ & 0 & 0 \\
\hline Portion with mild ${ }^{\mathrm{b}}$ haemophilia A & 22 & 244,500 & 216,250 & 0 & 0 \\
\hline Portion with haemophilia A of medium severity ${ }^{\mathrm{c}}$ & 38 & $3,055,200$ & 298,500 & 0 & 0 \\
\hline Portion with severe ${ }^{\mathrm{d}}$ haemophilia A & 120 & $12,109,200$ & $6,139,750$ & 0 & 0 \\
\hline Children and adolescents a with inhibitory bodies & 9 & $1,918,300$ & 548,500 & 0 & $110,120,000$ \\
\hline Portion low responder ${ }^{\mathrm{e}}$ & 4 & $1,012,300$ & 0 & 0 & $63,620,000$ \\
\hline Portion high responder ${ }^{\mathrm{f}}$ & 5 & 906,000 & 548,500 & 0 & $46,500,000$ \\
\hline Adults without inhibitory bodies & 332 & $22,694,800$ & $6,842,000$ & 0 & 0 \\
\hline Portion with mild ${ }^{\mathrm{b}}$ haemophilia A & 69 & 706,769 & 731,428 & 0 & 0 \\
\hline Portion with haemophilia A of medium severity ${ }^{\mathrm{c}}$ & 77 & $2,710,415$ & 715,286 & 0 & 0 \\
\hline Portion with severe ${ }^{\mathrm{d}}$ haemophilia A & 186 & $19,277,616$ & $5,395,286$ & 0 & 0 \\
\hline Adults with inhibitory bodies & 5 & $1,962,000$ & 504,000 & 530,000 & $605,080,000$ \\
\hline Portion low responder ${ }^{\mathrm{e}}$ & 1 & $1,122,600$ & 0 & 0 & 0 \\
\hline Portion high responder ${ }^{\mathrm{f}}$ & 4 & 839,400 & 504,000 & 530,000 & $605,080,000$ \\
\hline Total children and adolescents ${ }^{\mathrm{a}}$ & 189 & $17,327,200$ & $7,203,000$ & 0 & $110,120,000$ \\
\hline Total adults & 337 & $24,656,800$ & $7,346,000$ & 530,000 & $605,080,000$ \\
\hline Grand total & 526 & $41,984,000$ & $14,549,000$ & 530,000 & $715,200,000$ \\
\hline $\begin{array}{l}{ }^{\mathrm{a}} \mathrm{Up} \text { to age } 18 \text { years. } \\
{ }^{\mathrm{e}}<5 \text { Bethesda units } / \mathrm{ml} .\end{array}$ & $\begin{array}{l}{ }^{b}>5 \% \text { residual activity. } \\
{ }^{>}>5 \text { Bethesda units } / \mathrm{ml} .\end{array}$ & \multicolumn{2}{|c|}{ c2-5\% residual activity. } & \multicolumn{2}{|c|}{$\mathrm{d}^{\mathrm{d}}<2 \%$ residual activity. } \\
\hline
\end{tabular}




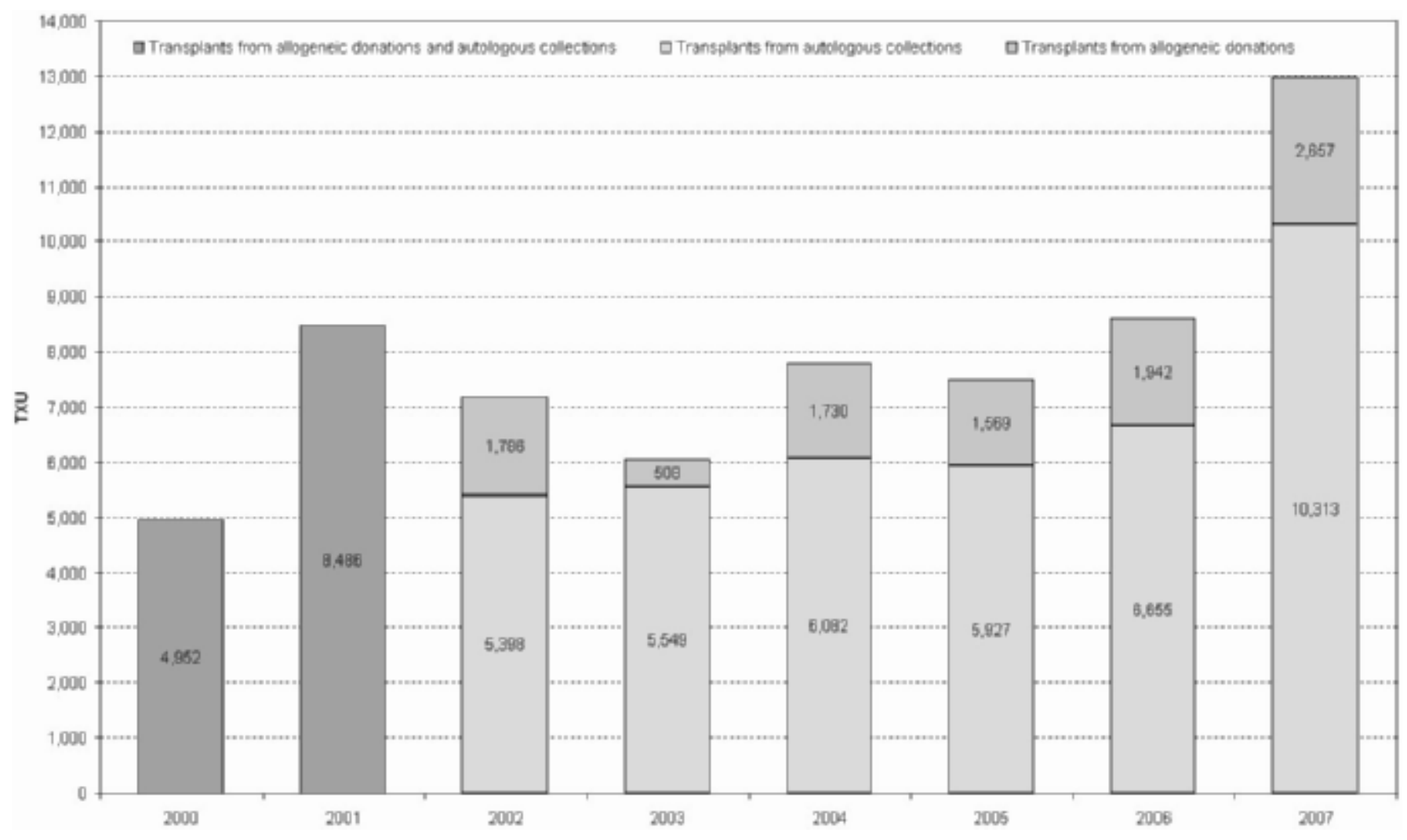

Fig. 13. Stem cells from umbilical cord blood. $T X U$ = individual dose for a transplant which can consist of several apheresis donations/bags.

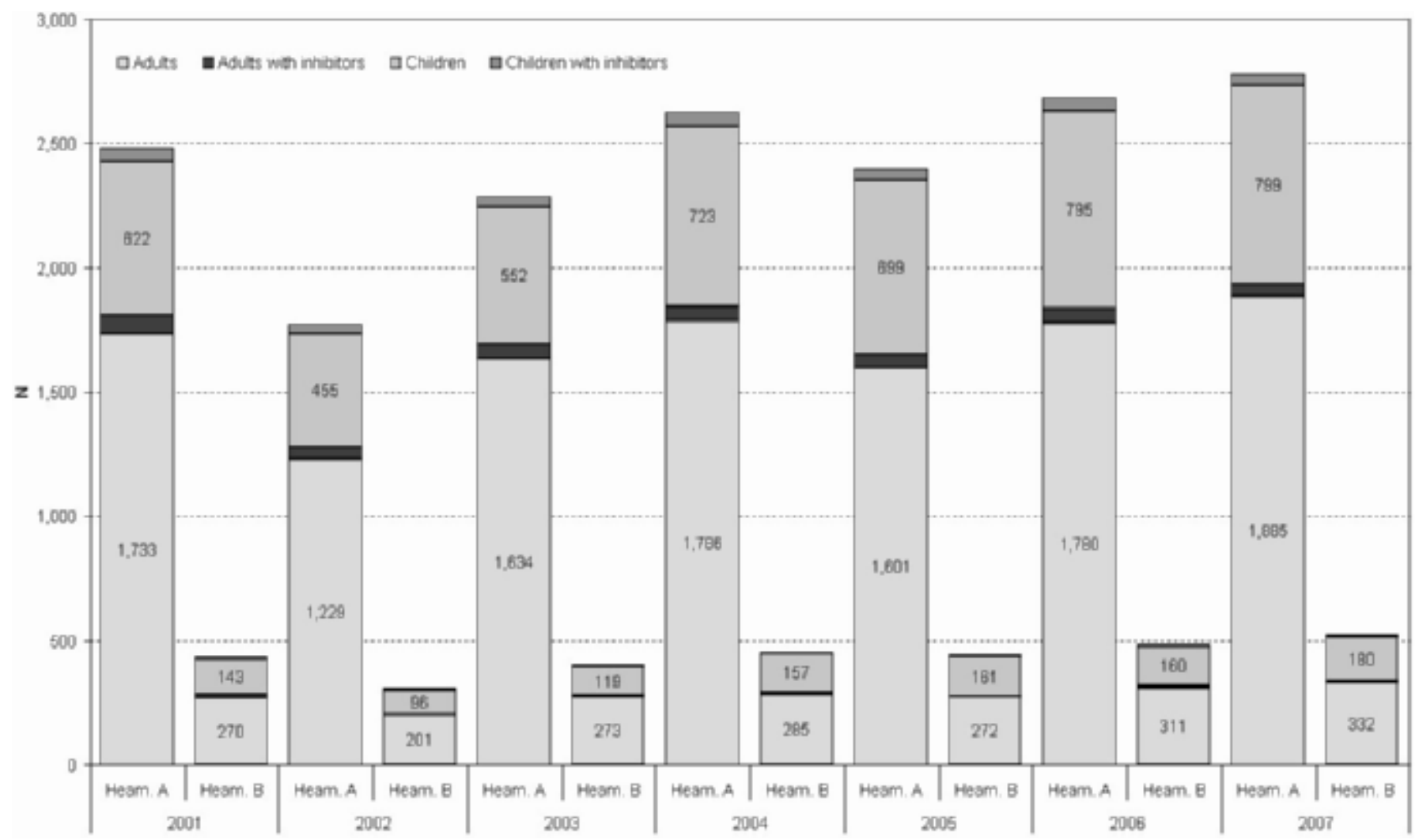

Fig. 14. Total number of haemophilia $A$ and haemophilia B patients. Each column shows the respective amounts (bottom up) among adults, adults with inhibitors, children and children with inhibitors. 


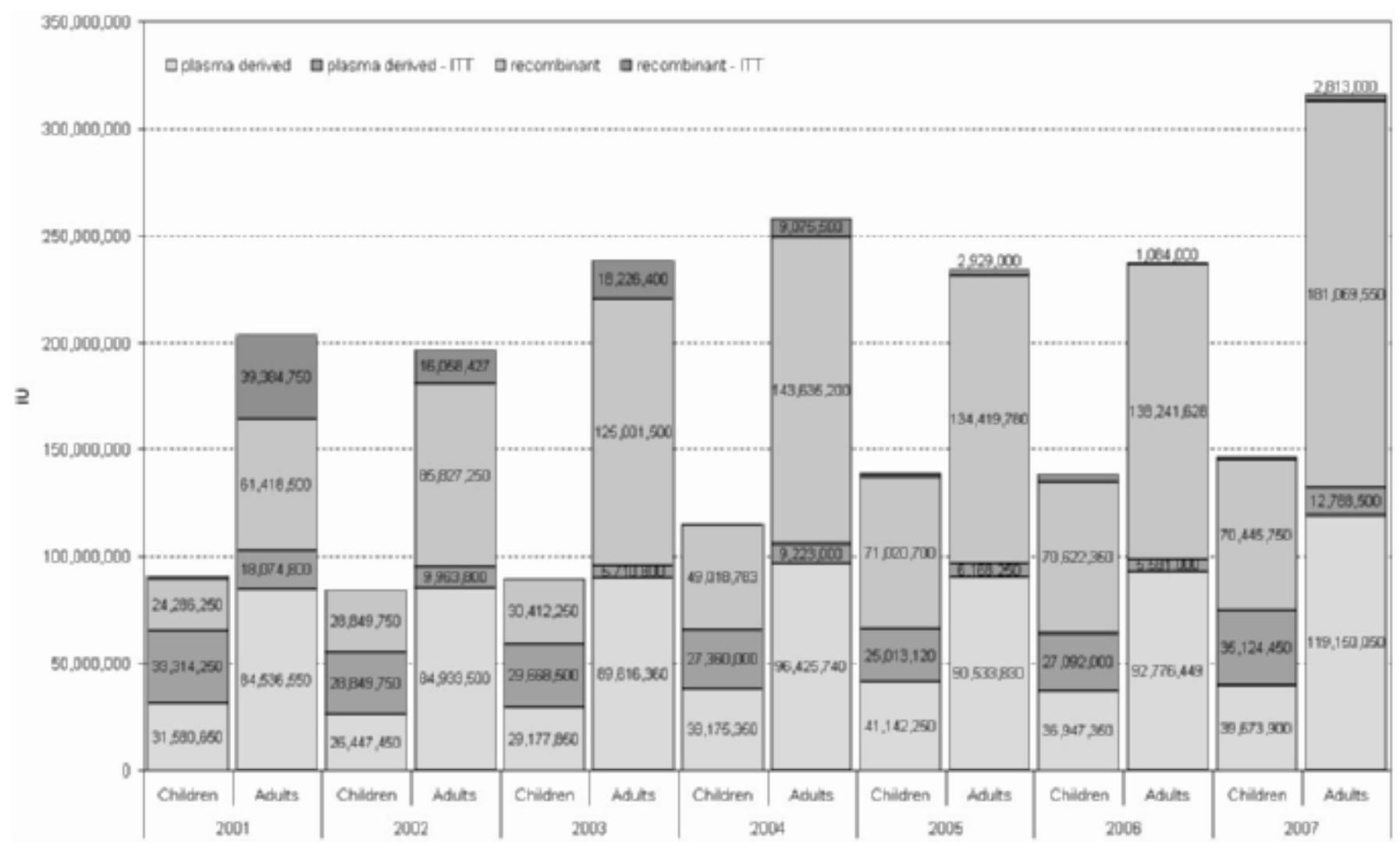

Fig. 15. Treatment of haemophilia A with recombinant and plasma-derived factor VIII concentrates among children and adults with or without immune tolerance therapy (ITT).

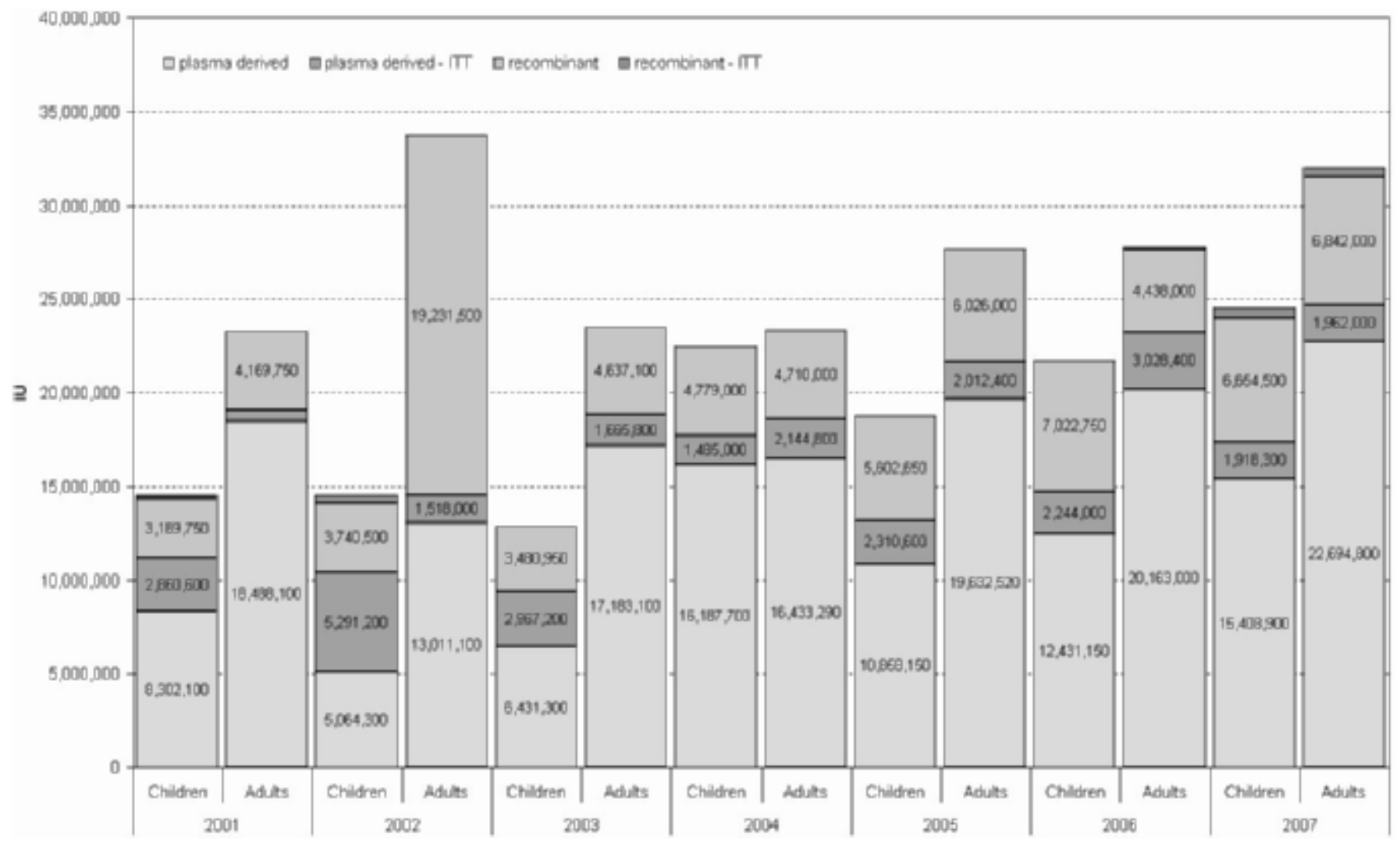

Fig. 16. Treatment of haemophilia B with recombinant and plasma-derived factor IX concentrates among children and adults with or without immune tolerance therapy (ITT). 
children was approximately $96 \%$ and among adults still approximately $82 \%$, based on the total amount of factor VIII prescribed in this patient group (fig. 15).

Both children and adult patients of haemophilia B have predominantly received factor IX from human plasma since 2003. In 2007 the figure was $74 \%$ regardless of availability of inhibitors (fig. 16).

As much as 672 patients with von Willebrand disease had been reported in 2007. These patients received 24,230,250 IU of von Willebrand factor-containing concentrates.

Statements with a higher informational value on the number of patients requiring treatment due to haemostasis disorder and their consumption of coagulation factors are expected in the near future by the data collection through the German Haemophilia Register.

\section{Acknowledgement}

The authors gratefully acknowledge the translation of the report by Mrs. C. Taylor, Paul-Ehrlich-Institut. The German version was published in Bundesgesundheitsblatt - Gesundheitsforschung - Gesundheitsschutz 2009;52:715-731.

\section{Disclosure}

The authors declared no conflict of interest.

\section{References}

1 The Collection, Testing and Use of Blood and Blood Products in Europe in 2005 , Draft Report. Strasbourg, Council of Europe Publishing, 2007.

2 Rejman A: The collection and use of human blood and plasma in the non-European Union Council of Europe Member States in 1997.Strasbourg, Council of Europe Publishing, 2000.

3 Trends and Observations on the Collection, Testing and Use of Blood and Blood Components in Europe: 2001-2005, Draft Report, unpublished.

4 Hay CRM: Harmonisation of National and International Databases for PTP Surveillance. Presentation at the ISTH Factor VIII and IX SSC, Vienna, July 5, 2008 